\title{
Cyclopropanations via Heme Carbenes: Basic Mechanism and Effects of Carbene Substituent, Protein Axial Ligand, and Porphyrin Substitution
}

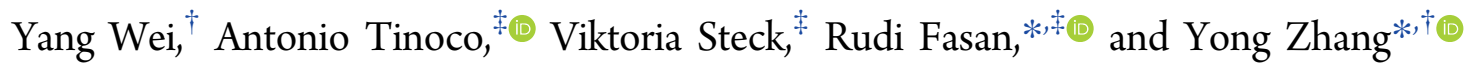 \\ ${ }^{\dagger}$ Department of Chemistry and Chemical Biology, Stevens Institute of Technology, 1 Castle Point on Hudson, Hoboken, New Jersey \\ 07030, United States of America
}

${ }^{\ddagger}$ Department of Chemistry, University of Rochester, 120 Trustee Road, Rochester, New York 14627, United States of America

\section{Supporting Information}

ABSTRACT: Catalytic carbene transfer to olefins is a useful approach to synthesize cyclopropanes, which are key structural motifs in many drugs and biologically active natural products. While catalytic methods for olefin cyclopropanation have largely relied on rare transition-metal-based catalysts, recent studies have demonstrated the promise and synthetic value of iron-based heme-containing proteins for promoting these reactions with excellent catalytic activity and selectivity. Despite this progress, the mechanism of iron-porphyrin and hemoprotein-catalyzed olefin cyclopropanation has remained largely unknown. Using a combination of quantum chemical calculations and experimental mechanistic analyses, the present study shows for the first time that the increasingly useful $\mathrm{C}=\mathrm{C}$ functionalizations mediated by heme carbenes feature an $\mathrm{Fe}^{\mathrm{II}}$-based, nonradical, concerted nonsynchronous mechanism,
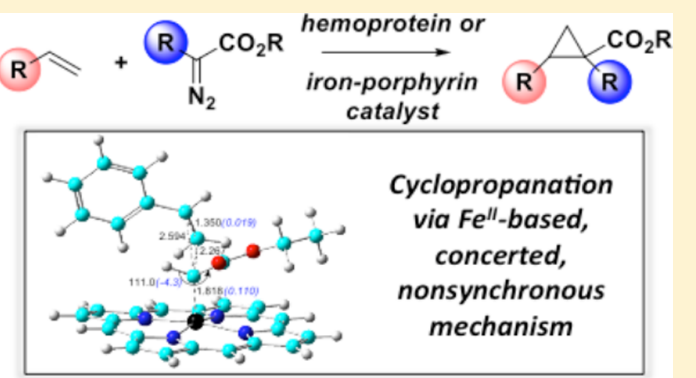

Axial ligand effect : imidazole $>$ thiolate $>$ no ligand Carbene substituent: $\mathrm{HCCO}_{2} \mathrm{R}>\mathrm{PhCCO}{ }_{2} \mathrm{R}>\mathrm{PhCPh}$ Porphyrin substitution: EWG \& $H B G$ reduce $\triangle G^{\ddagger}$ with early transition state character. This mechanism differs from the $\mathrm{Fe}^{\mathrm{IV}}$ based, radical, stepwise mechanism of heme-dependent monooxygenases. Furthermore, the effects of the carbene substituent, metal coordinating axial ligand, and porphyrin substituent on the reactivity of the heme carbenes was systematically investigated, providing a basis for explaining experimental reactivity results and defining strategies for future catalyst development. Our results especially suggest the potential value of electron-deficient porphyrin ligands for increasing the electrophilicity and thus the reactivity of the heme carbene. Metal-free reactions were also studied to reveal temperature and carbene substituent effects on catalytic vs noncatalytic reactions. This study sheds new light into the mechanism of iron-porphyrin and hemoprotein-catalyzed cyclopropanation reactions and it is expected to facilitate future efforts toward sustainable carbene transfer catalysis using these systems.

\section{INTRODUCTION}

Cyclopropanes are key structural motifs in many pharmaceuticals and biologically active molecules, ${ }^{1-5}$ which underscores the high synthetic values of catalytic methods for olefin cyclopropanation via carbene transfer. ${ }^{6-9}$ Metalloporphyrin systems have represented attractive catalysts for this type of reactions and major efforts in this area have focused on metalloporphyrins incorporating noble metals, such as $\mathrm{Rh}^{10-14}$ $\mathrm{Ru},{ }^{15-21} \mathrm{Os},{ }^{22-25}$ and $\mathrm{Ir}^{14,26-28}$ owing to the well-known reactivity of second- and third-row transition metals in carbene transfer reactions. ${ }^{6-9}$ More recently, the successful development and application of $\mathrm{Fe}^{29-37}$ and Co-porphyrins ${ }^{38-45}$ in cyclopropanation reactions have highlighted the potential of exploiting earth-abundant and inexpensive first-row transition metals for this important class of carbon-carbon bond forming reactions. Furthermore, very recent studies have revealed how iron-based, heme-dependent enzymes and proteins, such as cytochrome $\mathrm{P} 450^{46-49}$ and myoglobins, ${ }^{14,50-52}$ constitute promising biocatalysts for carbene-mediated cyclopropanation reactions. In particular, excellent enantioselectivity (>90-99\% ee) along with high catalytic activity $(>10,000$ turnovers $(\mathrm{TON})$ ) and broad substrate scope, have been recently achieved in olefin cyclopropanations using engineered myoglobin variants. ${ }^{50,51}$ These biocatalysts could be applied to the stereoselective synthesis of cyclopropane-containing drugs on a multigram scale outperforming current strategies to access these molecules. ${ }^{51}$ In addition to cyclopropanation reactions, myoglobins and other hemoproteins have proven useful for promoting a growing number of carbene-mediated transformations, including carbene insertion into $\mathrm{Y}-\mathrm{H}$ bonds $(\mathrm{Y}=\mathrm{N}, \mathrm{S}, \mathrm{Si}, \mathrm{C}),{ }^{53-57}$ aldehyde olefinations, ${ }^{58}$ and sigmatropic rearrangements. $^{59}$

Although iron porphyrin carbenes (IPCs) were implied in the aforementioned carbene-mediated transformations and in some cases directly shown to undergo cyclopropanation, ${ }^{31}$ the

Received: August 28, 2017

Published: December 22, 2017 
mechanism of cyclopropanation reactions catalyzed by hemoproteins and, more generally, $\mathrm{Fe}^{\mathrm{II}}$-porphyrins remains unknown. In biocatalytic cyclopropanations catalyzed by heme dependent proteins, the ferrous species was indeed determined to be the catalytically competent form of the metalloprotein. ${ }^{47,51}$ On the other hand, investigations of cyclopropanations with formally ferric iron-porphyrins suggest in situ reduction of the metalloporphyrin and thus the active role of $\mathrm{Fe}^{\mathrm{II}}$-porphyrin carbene in these reactions. ${ }^{29,32,36}$ Computationally, several different mechanisms have been proposed for metal carbene cyclopropanations, including elimination from metallocyclobutane $e^{60-62}$ and addition via both concerted ${ }^{63-65}$ and stepwise $^{66,67}$ pathways. Because both the metal center and ligand environment greatly influence the operating mechanism, it is critical to study the mechanism in newly developed systems such as the hemoprotein and $\mathrm{Fe}^{\mathrm{II}}$-porphyrin-based catalysts investigated here. Building on our recent progress in developing DFT methods for accurate predictions of $\mathrm{Fe}^{\mathrm{II}}$-porphyrin carbenes' experimental X-ray crystal structures, Mössbauer and NMR properties and IPC formations and $\mathrm{C}-\mathrm{H}$ insertions, ${ }^{68-70}$ here we report the first quantum chemical investigation of heme carbene-mediated cyclopropanation mechanism. The mechanistic model derived from our computational analyses is supported by experiments with isotopically labeled probe substrates and radical spin trapping reagents. In addition, this study performs the first systematic analysis of the effects of carbene substituent, protein axial ligand, and porphyrin substituent on cyclopropanation reactions. This study provides a mechanistic basis for explaining experimentally observed reactivity trends as well as key insights for guiding future development of iron-porphyrin-based (bio)catalysts for carbene-mediated cyclopropanations.

\section{RESULTS AND DISCUSSION}

Cyclopropanation Mechanism. The information of IPC's electronic nature is critical to understand its reactivity. Previously, a decade-long debate has concerned whether IPC is best described as $\mathrm{Fe}^{\mathrm{II}} \leftarrow\{: \mathrm{C}(\mathrm{X}) \mathrm{Y}\}^{0}$ or $\mathrm{Fe}^{\mathrm{IV}}=\{\mathrm{C}(\mathrm{X})$ $\mathrm{Y}\}^{2-31,32,71-74}$ The $\mathrm{Fe}^{\mathrm{IV}}$-based resonance structure, which is isoelectronic and analogous to the $\mathrm{Fe}^{\mathrm{IV}}=\mathrm{O}^{2-}$ group involved in cytochrome $\mathrm{P} 450$-catalyzed monooxygenation reactions, was discussed in IPC studies ${ }^{31}$ and it was proposed to mediate olefin cyclopropanations by engineered P450s and hemoproteins. $^{46,50}$ However, our recent studies ${ }^{68,69}$ show that it is the $\mathrm{Fe}^{\mathrm{II}}$-based and not the $\mathrm{Fe}^{\mathrm{IV}}$-based resonance structure that yields more accurate predictions of experimentally determined Mössbauer, X-ray, and NMR properties of IPCs, with calculated charges being consistent with the experimentally found electrophilic reactivity of this species. ${ }^{29,31,32,50,75}$ Challenging this view, a more recent computational study on iron-porphyrin catalyzed $\mathrm{N}-\mathrm{H}$ insertion proposes that a diradical, antiferromagnetically coupled $\mathrm{Fe}^{\mathrm{III}}\{\cdot \mathrm{C}(\mathrm{X}) \mathrm{Y}\}^{-}$complex with an openshell singlet (OSS) state is the most favored and thus the relevant IPC intermediate implicated in the carbene transfer process. ${ }^{76}$ Indirect support to the proposed carbon-centered radical catalytic intermediate was drawn from previous studies describing a radical mechanism for Co-porphyrin-catalyzed cyclopropanation $^{66,77}$ and other (nonheme) systems, ${ }^{7-80}$ albeit such claim was not verified experimentally. This mechanistic proposal is reminiscent of the radical nature of P450-catalyzed $\mathrm{C}-\mathrm{H}$ hydroxylation and epoxidation of certain olefins. ${ }^{81}$ The $\mathrm{Fe}^{\mathrm{IV}}=\mathrm{O}^{2-}$ species itself exhibits a radical feature as indicated by $\sim 0.9$ e spin density of the oxygen atom bound to formal $\mathrm{Fe}^{\mathrm{III}}{ }^{82,83}$ At the same time, the $\mathrm{Fe}^{\mathrm{III}}$-based OSS ground state does not appear to be fully consistent ${ }^{70}$ with the $\mathrm{Fe}^{\mathrm{II}}$ feature of isolated IPCs characterized by UV/vis and NMR spectroscopies, ${ }^{72,73} \mathrm{X}$-ray crystallography, ${ }^{31,72,84}$ and XANES, which is directly sensitive to the Fe oxidation state. ${ }^{84}$ In light of these divergent views and proposals about the electronic structure of IPCs involved in carbene transfer reactions and the unknown mechanism of hemoprotein-catalyzed cyclopropanation, we set to investigate this reaction through a combination of computations and experiments.

To this end, we initially investigated the cyclopropanation reaction involving styrene and the iron-porphyrin complex $\left[\mathrm{Fe}(\mathrm{TPFPP})\left(\mathrm{C}(\mathrm{Ph}) \mathrm{CO}_{2} \mathrm{Et}\right)\right](\mathrm{TPFPP}=$ meso-tetrakis $($ pentafluorophenyl)porphyrinato dianion), which was previously reported by Che and co-workers. ${ }^{31}$ In this reaction (referred to as reaction 1), two different pathways were considered and evaluated, namely an $\mathrm{Fe}^{\mathrm{II}}$-based concerted pathway (in blue) and an $\mathrm{Fe}^{\mathrm{III}}$-based radical stepwise pathway (in red) as shown in Scheme 1. The TPFPP was modeled as a nonsubstituted

\section{Scheme 1. Target Cyclopropanation Reactions ${ }^{a}$}

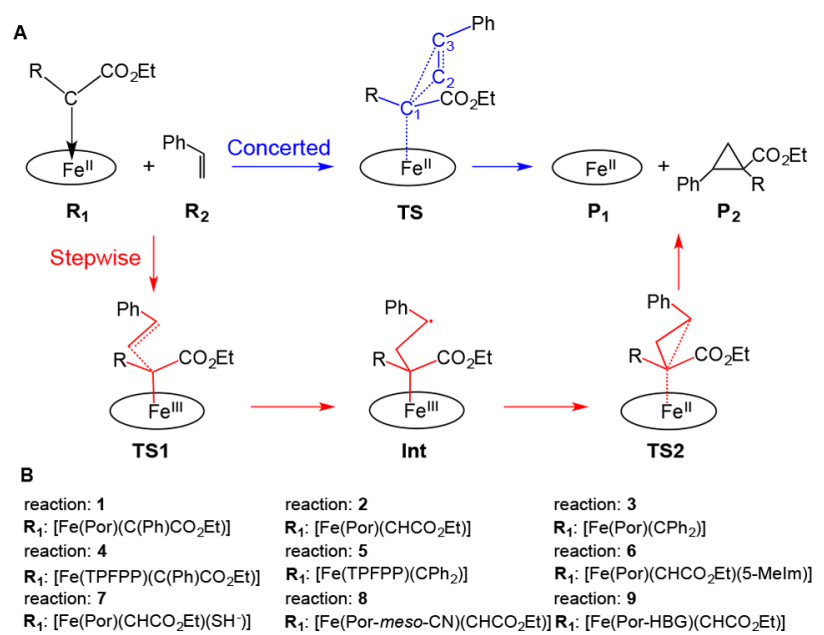

${ }^{a}$ (A) Concerted and stepwise pathway for $\mathrm{Fe}^{\mathrm{II}}$-porphyrin catalyzed cyclopropanation of styrene. Oval represents the porphyrin ligand. (B) Reactions 1-9 involving different reactants $\left(\mathbf{R}_{1}\right)$.

porphyrin (Por) as done previously. ${ }^{68,69}$ Experimental spin states of iron-containing reactant $R_{1}(\mathbf{1})$ and product $P_{1}(\mathbf{1})$ (here the number in parentheses after the reaction species symbol indicates the reaction number used in this work) are singlet and triplet respectively, ${ }^{31,85}$ which were well reproduced in our recent studies of other related chemical reactions. ${ }^{69,70}$ To determine the favored spin state for the transition state, both singlet and triplet pathways were considered. We first investigated the concerted mechanism. Transition states leading to both the trans and cis product were obtained. Only the pathways leading to trans- $1 R, 2 S$ and cis- $1 R, 2 R$ cyclopropanes were studied, as the other two possible products are mirror images of these isomers.

Our results show that the singlet transition state is less favorable than the triplet transition state (see Table S4), which features a $\mathrm{Fe}^{\mathrm{II}}(\mathrm{S}=1)$ center with nonradical character for carbene, styrene, and porphyrin based on the calculated negligible spin densities reported in Table S5. Using brokensymmetry initial setups of $\mathrm{Fe}^{\mathrm{III}}$ ferromagnetically and antiferromagnetically coupled with carbene radical for triplet and singlet transition states, respectively, led to basically the 
same $\mathrm{Fe}^{\mathrm{II}}$-based results after geometry optimizations, suggesting the dominant $\mathrm{Fe}^{\mathrm{II}}$ feature for the concerted mechanism. The smaller $\Delta G^{\ddagger}$ value for the pathway leading to the trans product (18.58 kcal $/ \mathrm{mol}$ ) compared to that yielding the cis isomer $(20.75 \mathrm{kcal} / \mathrm{mol})$ is consistent with the experimentally found trans selectivity of the reaction. ${ }^{31}$ This selectivity may be a result of favorable $\pi-\pi$ interactions between the phenyl rings of the carbene moiety and styrene and one more short attractive $\mathrm{O} \cdots \mathrm{H}$ interaction as illustrated in Figure $1 \mathrm{~A}$ and $1 \mathrm{~B}$.

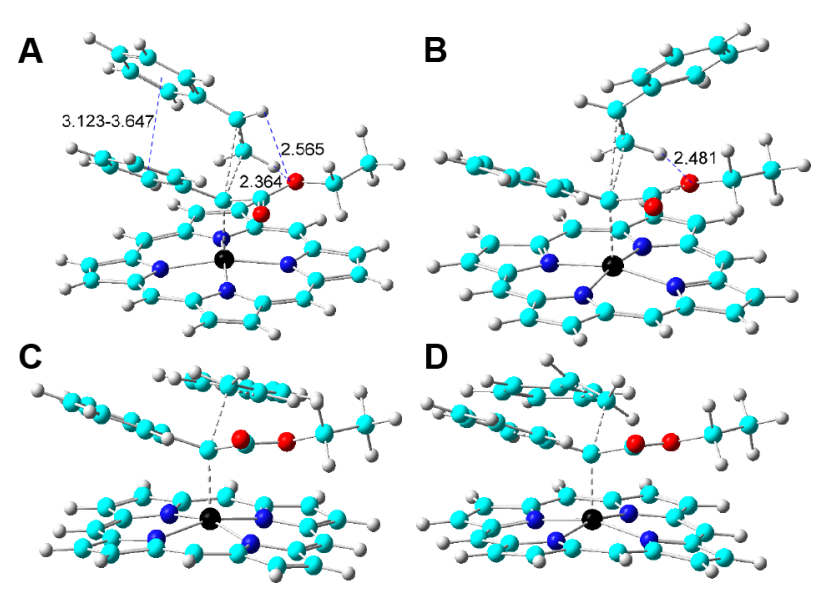

Figure 1. (A) $\mathrm{TS}_{\text {trans }} ;$ (B) $\mathrm{TS}_{\text {cis }} ;$ (C) TS1 $1_{\text {trans }} ;$ (D) $\mathrm{TS}_{\text {cis }}$ in reaction 1. Atom color scheme: Fe, black; C, cyan; N, blue; $\mathrm{O}$, red; $\mathrm{H}$, gray.

For the stepwise mechanism (red, Scheme 1), the first transition state, TS1(1), which is the bottleneck step compared to TS2(1) in Co porphyrin cyclopropanation, ${ }^{66}$ was obtained for both trans and cis isomers. Interestingly, in this case, with initial setups of ferric center and radical carbene/styrene, the optimized structures maintain some radical feature. For instance, the C3 carbon atom (see Scheme 1 for atomic labels) has spin densities of 0.280 and 0.384 e for triplet $\operatorname{TS}_{\text {trans }}(\mathbf{1})$ and $\operatorname{TS} 1_{\text {cis }}(1)$, and it has even larger spin densities of $-0.531 /-$ $0.567 \mathrm{e}$ in the corresponding singlet $\mathbf{T S} 1_{\text {trans }}(\mathbf{1})$ and $\mathbf{T S} \mathbf{1}_{\text {cis }}(\mathbf{1})$ (Table S5). The iron spin densities of $1.373 / 1.375$ e in these singlet transition states coupled with $-0.813 /-0.809$ e spin densities of the carbene carbon atom suggest an $\mathrm{Fe}^{\mathrm{III}}$-based OSS feature, whereas the iron spin densities of $\sim 1.9$ e and carbene carbon spin densities of $\sim 0.1$ e in the triplet transition states indicate a major $\mathrm{Fe}^{\mathrm{II}}$ feature. For the radical pathway, the $\mathrm{Fe}^{\mathrm{III}}$-based OSS transition states are more favorable than the $\mathrm{Fe}^{\mathrm{II}}$ triplet states by $3-8 \mathrm{kcal} / \mathrm{mol}$ (Table S4) and more favorable than the $\mathrm{Fe}^{\mathrm{II}}$-based CSS transition states leading to the trans and cis products by 9.10 and $12.67 \mathrm{kcal} / \mathrm{mol}\left(\Delta \Delta G^{\ddagger}\right)$, respectively, which make them indeed the most favorable states for this stepwise mechanism. Regarding the geometries of these $\mathrm{Fe}^{\mathrm{III}}$-based OSS, there is only one short distance between the carbene carbon and the $\alpha$ and $\beta$ carbons of styrene $\left(R_{\mathrm{C} 1 \mathrm{C} 2} \sim\right.$ $2.2 \AA, R_{\mathrm{C} 1 \mathrm{C} 3} \sim 3.1 \AA$ ), as shown in Figure $1 \mathrm{C}, \mathrm{D}$ and Table $S 5$, and as expected for the stepwise attack. Interestingly, the $\Delta G^{\ddagger}$ difference between trans and cis transition states in this stepwise pathway is only $0.8 \mathrm{kcal} / \mathrm{mol}$, which is smaller than the $\sim 2$ $\mathrm{kcal} / \mathrm{mol}$ difference in the concerted pathway and is similar to $0.3 \mathrm{kcal} / \mathrm{mol}$ difference for styrene radical cyclopropanation catalyzed by Co-porphyrin. As shown in Figure 1C,D, the aromatic ring of styrene adopts a conformation parallel to the plane of the porphyrin ring, which differs from the tilted conformation observed in the concerted pathway (Figure $1 \mathrm{~A}, \mathrm{~B})$. In this radical stepwise mechanism, initial conformations analogous to those observed in the concerted pathway and initial conformations in which the phenyl ring is perpendicular to the porphyrin ring were also investigated. In all cases, all conformations converged to that observed in the concerted pathway after geometry optimization. This suggests a preference for the concerted pathway. In fact, the $\Delta G^{+}$values for both $T S 1_{\text {trans }}(\mathbf{1})$ and $T S 1_{\text {cis }}(1)$ in this stepwise pathway are higher than the corresponding $\mathbf{T S}_{\text {trans }}(1)$ and $\mathbf{T S}_{\mathrm{cis}}(\mathbf{1})$ in the concerted pathway by $4-7 \mathrm{kcal} / \mathrm{mol}$ (Table S6). The electronic energies, zero-point energy corrected electronic energies, and
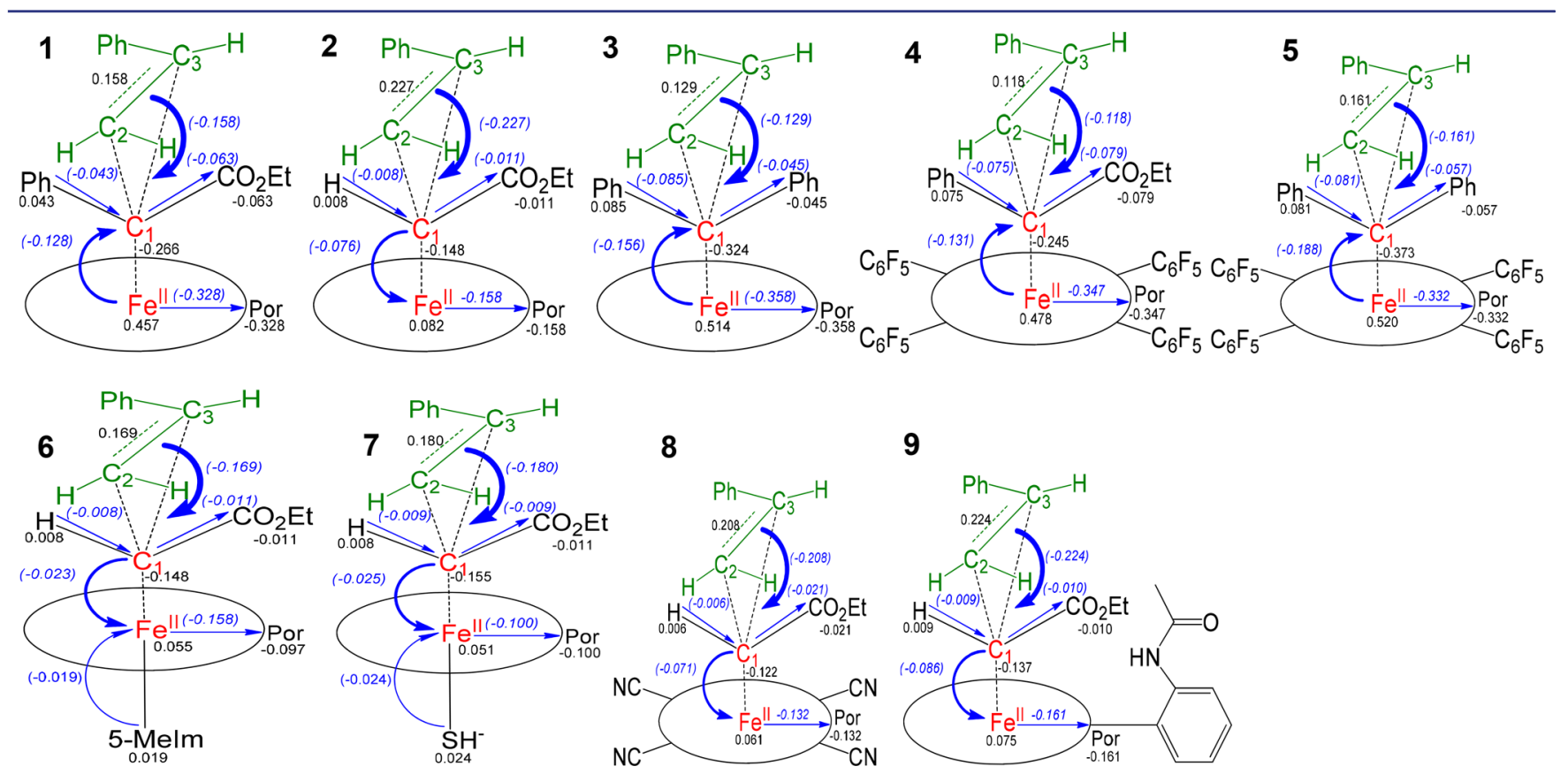

Figure 2. (1-9) Atomic charge changes from reactants to transition state (in black) and charge transfers (in blue) as indicated by arrows and numbers in parentheses in reactions $\mathbf{1 - 9}$. 

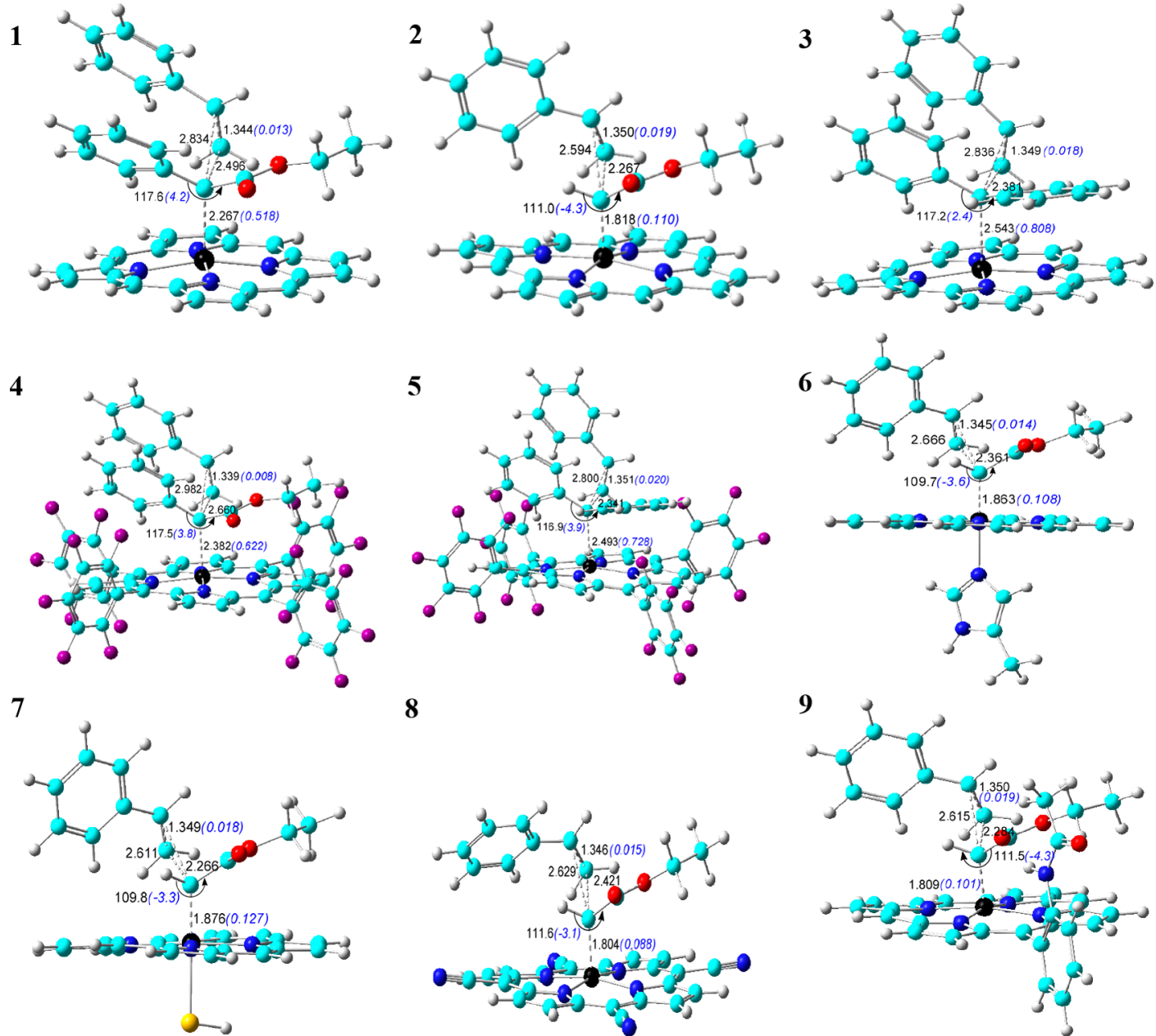

8

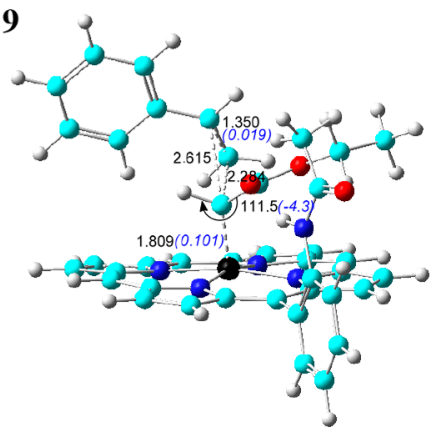

Figure 3. (1-9) Key geometric parameters at transition state (in black) and changes from reactants to transition state (in blue) in reactions 1-9. Atom color scheme: Fe, black; O, red; C, cyan; H, gray; F, purple; S, yellow.

enthalpies exhibit the same trend, which clearly indicate that the radical, stepwise pathway is unfavorable compared to the concerted pathway. Based on these results, subsequent steps in the unfavorable, radical pathway were not further considered and we focused our attention on the concerted pathway leading to the trans cyclopropanation product, which is the favored product in the presence of synthetic iron porphyrin catalysts ${ }^{30}$ and myoglobins. ${ }^{50,51}$

As illustrated by the data in Figure 2-1, charge analysis shows a significant charge transfer (CT) from the olefin substrate to the carbene moiety, a result consistent with the experimentally determined electrophilicity of the latter. ${ }^{31,50}$ As shown in Figure 3-1, the most significant geometric change at the transition state $\mathrm{TS}_{\text {trans }}(1)$ relative to the reactants is the elongation of the $\mathrm{Fe}$ carbene distance $\left(R_{\mathrm{FeCl}}\right)$ by about $\sim 0.5 \AA$ to accommodate attack of the carbene group on the $\mathrm{C}=\mathrm{C}$ bond of styrene. At this step, both the elongation of the $\mathrm{C}=\mathrm{C}$ bond $\left(R_{\mathrm{C} 2 \mathrm{C} 3}\right)$ and the change in the bond angle between the carbene substituents $\left(\mathrm{Ph}-\mathrm{C}-\mathrm{CO}_{2} \mathrm{Et}\right)$ are modest $\left(0.013 \AA\right.$ and $4.2^{\circ}$, respectively). These minor structural changes along with the $117.6^{\circ}$ value for the $\mathrm{Ph}-\mathrm{C}-\mathrm{CO}_{2} \mathrm{Et}$ bond angle indicate that the carbene carbon in the transition state is still largely $\mathrm{sp}^{2}$-hydridized as in the reactant, rather than exhibiting $\mathrm{sp}^{3}$ geometry as in the product. Altogether, these structural features suggest that this is an early transition state. Furthermore, a difference of about 0.3 $\AA$ between the $\mathrm{C} 1 \cdots \mathrm{C} 2$ and $\mathrm{C} 1 \cdots \mathrm{C} 3$ distances indicate the nonsynchronous character of the carbene addition process to the olefin, as illustrated in Figure 3-1.

To verify these predictions experimentally, mechanistic studies were performed using styrene (1a) as the olefin substrate, ethyl diazoacetate (EDA, 2) as the carbene donor, and iron-tetraphenyl porphyrin (Fe(TPP)), hemin (ironprotoporphyrin IX or $\mathrm{Fe}(\mathrm{ppIX})$ ), or myoglobin $(\mathrm{Mb})$ as the catalyst. As for the biocatalysts, we evaluated both wild-type sperm whale $\mathrm{Mb}$ and its engineered variant $\mathrm{Mb}(\mathrm{H} 64 \mathrm{~V}, \mathrm{~V} 68 \mathrm{~A})$, which displays significantly enhanced catalytic activity $(>10,000$ vs $180 \mathrm{TON}$ for $\mathrm{Mb})$ as well as excellent trans-(1S,2S)diastereo- and enantioselectivity ( $>99 \%$ de and ee vs $86 \%$ de and $0 \%$ ee for $\mathrm{Mb}$ ) in the cyclopropanation of vinylarenes with EDA. ${ }^{50}$ To investigate the occurrence of stepwise vs concerted mechanism, we initially carried out the cyclopropanation reactions in the presence of cis- $\beta$-deutero-styrene $(\mathbf{1} \mathbf{b}$, Table 1 ), which was meant to probe the formation of a carboncentered radical intermediate $(\operatorname{Int}(\mathbf{1})$, Scheme 1$)$. Indeed, a stereospecific reaction resulting in a cis configuration relative to the $-\mathrm{D}$ and $-\mathrm{Ph}$ group in the corresponding cyclopropanation product would be expected in the case of a concerted mechanism, whereas (partial) cis/trans isomerization would be revealing of the intermediacy of a radical species. Importantly, the isolated trans-2-phenyl-1-ethyl carboxylate cyclopropane products from the reactions catalyzed by $\mathrm{Fe}(\mathrm{TPP})$, wild-type $\mathrm{Mb}$, and $\mathrm{Mb}(\mathrm{H} 64 \mathrm{~V}, \mathrm{~V} 68 \mathrm{~A})$ all consisted 
Table 1. Biocatalytic and Chemocatalytic Cyclopropanation Reactions with cis- $\beta$-Deutero-styrene

\begin{tabular}{|c|c|c|c|c|c|}
\hline 1b & 2 & \multicolumn{3}{|c|}{$\begin{array}{c}\mathrm{J}_{H \alpha-H \beta}=9.2 \mathrm{~Hz} \\
\delta(\mathrm{D}-\mathrm{NMR}): 1.32 \mathrm{ppm}\end{array}$} & $\begin{array}{c}\text { 3b } \\
\mathrm{H}=7.2 \mathrm{~Hz} \\
\mathrm{MR}): 1.72 \mathrm{ppm}\end{array}$ \\
\hline Entry & Catalyst & $\begin{array}{c}\text { Reaction } \\
\text { Conditions }{ }^{a}\end{array}$ & Yield $^{b}$ & $\begin{array}{l}\text { Ratio } \\
3 \mathbf{a}: 3 \mathbf{b}^{c}\end{array}$ & $\%$ isomeriz. \\
\hline 1 & $\mathrm{Mb}(\mathrm{H} 64 \mathrm{~V}, \mathrm{~V} 68 \mathrm{~A}$ & A & $48 \%$ & $1: 0$ & $0 \%$ \\
\hline 2 & $\mathrm{Mb}$ & A & $3 \%$ & $1: 0$ & $0 \%$ \\
\hline 3 & $\mathrm{Fe}(\mathrm{ppIX})$ & $\mathbf{A}$ & $24 \%$ & 1:0.017 & $1.7 \%$ \\
\hline 4 & $\mathrm{Fe}(\mathrm{TPP})$ & B & $14 \%$ & $1: 0$ & $0 \%$ \\
\hline 5 & $\mathrm{Co}(\mathrm{TPP})$ & B & $5 \%$ & $1: 0.66$ & $39.7 \%$ \\
\hline
\end{tabular}

${ }^{a}$ Reaction conditions A: $200 \mathrm{mM} \mathrm{1,} 400 \mathrm{mM}$ EDA, $60 \mu \mathrm{M} \mathrm{Mb}$ variant (or hemin), $10 \mathrm{mM}$ sodium dithionite in $50 \mathrm{mM}$ potassium phosphate buffer ( $\mathrm{pH} \mathrm{7)}$ containing 10\% DMF, room temp., 16 h. Reaction conditions B: $0.475 \mathrm{mmol} \mathrm{1,} 1.5$ equiv EDA (slow addition), $5 \mathrm{~mol} \%$ catalyst in $\mathrm{CH}_{2} \mathrm{Cl}_{2}, 40{ }^{\circ} \mathrm{C}, 16 \mathrm{~h}$. ${ }^{b}$ Isolated yield for trans-configured product relative to $\mathrm{Ph}$ and $\mathrm{CO}_{2} \mathrm{Et}$ groups (racemic for all reactions except with $\mathrm{Mb}(\mathrm{H} 64 \mathrm{~V}, \mathrm{~V} 68 \mathrm{~A}) .{ }^{c}$ Based on peak integration in ${ }^{2} \mathrm{H} \mathrm{NMR}$ spectrum.

of the syn addition product 3a, as determined by ${ }^{1} \mathrm{H}$ and ${ }^{2} \mathrm{H}$ NMR spectroscopy (Table 1, Entries 1-2, 4). A detectable albeit negligible amount of diastereomer $3 \mathbf{b} \quad(<2 \%)$ was observed with hemin (Entry 3 ). In stark contrast, a significant degree of cis/trans isomerization (39.7\%) was obtained in the same reaction using $\mathrm{Co}(\mathrm{TPP})$ as the catalyst (Entry 5), a result that is consistent with the previously reported radical mechanism of $\mathrm{Co}$ (TPP)-catalyzed cyclopropanation. ${ }^{66,77} \mathrm{Im}$ portantly, the stereospecificity of the cyclopropanation reaction catalyzed by $\mathrm{Fe}(\mathrm{TPP})$ and the myoglobin variants strongly support a concerted, nonradical pathway for the cyclopropanation reaction catalyzed by iron-porphyrins.

To further corroborate these conclusions, cyclopropanation reactions with styrene (1a) and EDA (2) were then carried out in the presence of the radical spin trapping agent 5,5-dimethyl1-pyrroline N-oxide (DMPO). As shown in Table 2, no effect in product yield was observed for the reactions catalyzed by the myoglobin variants or hemin, in the presence of DMPO when compared to parallel reactions performed in its absence (Entries 1, 3, and 5 vs 2, 4, and 6, respectively). In stark contrast, a dramatic reduction in product yield $(\sim 90 \%$ reduction) was observed for the $\mathrm{Co}$ (TPP)-catalyzed reaction upon addition of the radical trapping reagent (Entry 7 vs 8 ). These results thus agree with those obtained with $c i s-\beta$-deuterostyrene in evidencing a nonradical mechanism for ironporphyrin and hemoprotein-catalyzed cyclopropanation. As such, these studies provide strong experimental support to the proposed concerted mechanism for IPC-mediated cyclopropanation, as derived from our computational analyses. Furthermore, the small secondary kinetic isotope effect (KIE) determined for the $\mathrm{Mb}(\mathrm{H} 64 \mathrm{~V}, \mathrm{~V} 68 \mathrm{~A})$-catalyzed cyclopropanation of styrene versus perdeuterated $d_{8}$-styrene $\left(k_{\mathrm{H}} / k_{\mathrm{D}}=0.96 \pm\right.$ $0.02)^{50}$ suggests a minimal extent of rehybridization of the olefin carbon atoms in the transition state, which is consistent with the reagent-like early transition-state predicted by our computations (Figure 3-1). For this reaction, a KIE of 0.99 was obtained by computation, which is in excellent accord with the experimentally determined value (0.96). ${ }^{50}$

Carbene Substituent Effect. With the basic mechanism of IPC-mediated cyclopropanation revealed above, we then extended our computational analyses to the study of the carbene substituent effect. We first examined the cyclopropanation of styrene with $\left[\mathrm{Fe}(\mathrm{Por})\left(\mathrm{CHCO}_{2} \mathrm{Et}\right)\right]$ derived from EDA (reaction 2), a carbene donor reagent extensively investigated in hemoprotein- ${ }^{46,47,49-51}$ and iron-porphyrincatalyzed cyclopropanations. ${ }^{29-33,36,37}$ Interestingly, the singlet transition state in this reaction is more favorable than the triplet state by $\Delta G$ of $1.02 \mathrm{kcal} / \mathrm{mol}$. This effect may be attributed to the reduced steric hindrance of the $\mathrm{CHCO}_{2} \mathrm{Et}$ vs $\mathrm{C}(\mathrm{Ph}) \mathrm{CO}_{2} \mathrm{Et}$ moiety, which allows for a closer distance between the carbene carbon atom and $\mathrm{Fe}(\sim 0.5 \AA)$ and thus a stronger field strength effect on the iron center, which favors the low spin state. Furthermore, the computed $\Delta G^{\ddagger}$ for this step $(12.47 \mathrm{kcal} / \mathrm{mol})$ is significantly smaller $(\sim 6 \mathrm{kcal} / \mathrm{mol})$ than that for the corresponding transition state in the reaction with $[\mathrm{Fe}$ (Por)$\left.\left(\mathrm{C}(\mathrm{Ph}) \mathrm{CO}_{2} \mathrm{Et}\right)\right]$ (reaction $\left.\mathbf{1}\right)$, indicating a more facile cyclopropanation reaction with the IPC intermediate derived from EDA. The elevated reactivity of the latter may arise from the increased charge transfer from the substrate to the carbene by

Table 2. Cyclopropanation Reactions in the Presence or Absence of Free-Radical Spin Trapping Agent

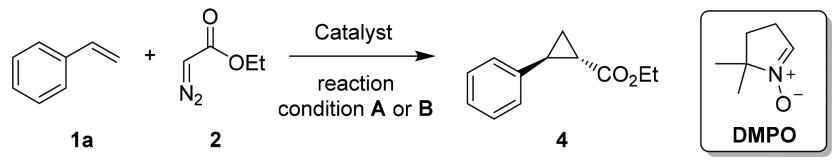

1a

Reaction Conditions $^{a}$
A
A
A
A
A
A
B
B

$\begin{array}{cr}\text { DMPO }^{b} & \text { Yield }^{c} \\ \text { No } & 86 \% \\ \text { Yes } & 82 \% \\ \text { No } & 27 \% \\ \text { Yes } & 35 \% \\ \text { No } & 8 \% \\ \text { Yes } & 13 \% \\ \text { No } & 76 \% \\ \text { Yes } & 8 \%\end{array}$

$\begin{array}{cc}\% d e^{d} & \% e e^{d} \\ 99 & 99 \\ 99 & 98 \\ 89 & 3 \\ 90 & 1 \\ 87 & 0 \\ 87 & 0 \\ 49 & 0 \\ 29 & 0\end{array}$

${ }^{a}$ Reaction conditions A: $10 \mathrm{mM}$ styrene, $20 \mathrm{mM}$ EDA, $20 \mu \mathrm{M} \mathrm{Mb}$ variant (or hemin), $10 \mathrm{mM}$ sodium dithionite in $50 \mathrm{mM}$ potassium phosphate buffer ( $\mathrm{pH} 7$ ) containing 10\% DMF, room temp., $16 \mathrm{~h}$. Reaction conditions B: 0.24 mmol styrene, 1.5 equiv EDA (slow addition), 5 mol \% $\mathrm{Co}(\mathrm{TPP})$ in $\mathrm{CH}_{2} \mathrm{Cl}_{2}, 40{ }^{\circ} \mathrm{C}, 16 \mathrm{~h}$. ${ }^{b}$ With or without 10 equiv DMPO relative to styrene. ${ }^{c} \mathrm{GC}$ yield. ${ }^{d}$ Diastereomeric $(d e)$ and enantiomeric excess (ee) for trans- $(1 S, 2 S)$ cyclopropane product. 
Table 3. Key Energy, Charge, and Geometry Parameters ${ }^{a}$

\begin{tabular}{|c|c|c|c|c|c|c|c|}
\hline Reaction & $\Delta G^{\dagger}(\mathrm{kcal} / \mathrm{mol})$ & $\Delta G^{\circ}(\mathrm{kcal} / \mathrm{mol})$ & $Q_{C T}(\mathrm{e})$ & $\Delta Q_{\mathrm{C} 1}(\mathrm{e})$ & $\Delta R_{\mathrm{C} 2 \mathrm{C} 3}(\AA)$ & $R_{\mathrm{C} 2 \mathrm{C} 3}^{\mathrm{TS}}(\AA)$ & $\Delta R_{\mathrm{FeCl}}(\AA)$ \\
\hline 1 & 18.58 & -35.50 & 0.158 & -0.266 & 0.013 & 1.344 & 0.518 \\
\hline 2 & 12.47 & -39.18 & 0.227 & -0.148 & 0.019 & 1.350 & 0.110 \\
\hline 3 & 19.74 & -30.43 & 0.129 & -0.324 & 0.018 & 1.349 & 0.808 \\
\hline 4 & 16.25 & -17.46 & 0.118 & -0.245 & 0.008 & 1.339 & 0.622 \\
\hline 5 & 21.89 & -11.69 & 0.161 & -0.373 & 0.020 & 1.351 & 0.728 \\
\hline 6 & 9.24 & -56.65 & 0.169 & -0.142 & 0.014 & 1.345 & 0.108 \\
\hline 8 & 7.49 & -36.14 & 0.208 & -0.122 & 0.015 & 1.346 & 0.088 \\
\hline 9 & 11.90 & -41.27 & 0.223 & -0.137 & 0.019 & 1.350 & 0.101 \\
\hline
\end{tabular}

${ }^{a}$ Results are for the most favorable trans products. Changes are those at transition state compared with reactants.

0.069 e due to shorter substrate-carbene distance $\left(\Delta R_{\mathrm{C} 1 \mathrm{C} 2}\right.$ of $0.229 \AA$ and $\Delta R_{\mathrm{C} 1 \mathrm{C} 3}$ of $0.240 \AA$ ).

To further investigate this aspect, we analyzed reaction 3 , in which $\left[\mathrm{Fe}(\mathrm{Por})\left(\mathrm{CPh}_{2}\right)\right]$ is used as the carbene source. As shown in Table 3, the $\Delta G^{\ddagger}$ for this reaction is higher than that in the reaction with $\left[\mathrm{Fe}(\right.$ Por $\left.)\left(\mathrm{C}(\mathrm{Ph}) \mathrm{CO}_{2} \mathrm{Et}\right)\right]$ by $1.16 \mathrm{kcal} /$ mol. Therefore, the electron-withdrawing effect (EWG) of the $\mathrm{CO}_{2} \mathrm{Et}$ group in reaction 1 enhances the reaction rate as compared to the electron-donating phenyl group in reaction 3 . This result is consistent with the substrate-to-carbene CT effect highlighted above, whereby the EWG group in the carbene moiety facilitates the reaction, as reflected by an increased CT of 0.029 e for the transition state involving $[\mathrm{Fe}(\mathrm{Por})(\mathrm{C}(\mathrm{Ph})$ $\left.\left.\mathrm{CO}_{2} \mathrm{Et}\right)\right]$ vs $\left[\mathrm{Fe}(\right.$ Por $\left.)\left(\mathrm{CPh}_{2}\right)\right]$ (Figure 2-1 vs $2-3$ ). This result agrees with the experimentally observed higher reactivity of $\left[\mathrm{Fe}(\mathrm{TPFPP})\left(\mathrm{C}(\mathrm{Ph}) \mathrm{CO}_{2} \mathrm{Et}\right)\right]$ compared to $[\mathrm{Fe}(\mathrm{TPFPP})-$ $\left.(\mathrm{CPh})_{2}\right]$ in stoichiometric cyclopropanations. ${ }^{31}$ However, the reactivity difference in these experiments is more pronounced than anticipated by our calculations, as indicated by the $82 \%$ yield $(=82$ TON $)$ obtained with $\left[\mathrm{Fe}(\mathrm{TPFPP})\left(\mathrm{C}(\mathrm{Ph}) \mathrm{CO}_{2} \mathrm{Et}\right)\right]$ and styrene, compared to the lack of reactivity for $[\mathrm{Fe}-$ $\left.(\mathrm{TPFPP})(\mathrm{CPh})_{2}\right]$ even at elevated temperatures and extended reaction times. We attribute this difference to the porphyrin substituent effect, which was absent in our initial calculations. We then calculated the cyclopropanation pathways using authentic $\left[\mathrm{Fe}(\mathrm{TPFPP})\left(\mathrm{C}(\mathrm{Ph}) \mathrm{CO}_{2} \mathrm{Et}\right)\right]$ (reaction 4) and $[\mathrm{Fe}-$ $\left.(\mathrm{TPFPP})(\mathrm{CPh})_{2}\right]$ (reaction 5). As shown in Table 3, a similar trend was observed in these reactions but a significantly larger $\Delta \Delta G^{\ddagger}(5.64 \mathrm{kcal} / \mathrm{mol})$ was found for reaction 5 vs reaction 4 . This result is thus more in line with the dramatic reactivity difference observed experimentally. Altogether, the computational analyses described above highlight the important role of the carbene substituent in affecting the reactivity of the IPC intermediate in cyclopropanation reactions.

To examine experimentally the carbene substituent effect on the (bio)catalytic cyclopropanation reactions, side-by-side experiments were performed using EDA vs ethyl 2-diazo-2phenyl-acetate (EDPA, 6) as the carbene donor in the presence of $\mathrm{Mb}(\mathrm{H} 64 \mathrm{~V}, \mathrm{~V} 68 \mathrm{~A})$, hemin or $\mathrm{Fe}(\mathrm{TPP})$ as the catalyst (Table 4). For these reactions, 4-methoxy-styrene (5) was used as the olefin substrate instead of the more volatile styrene because of the application of elevated temperatures $\left(50{ }^{\circ} \mathrm{C}\right)$ for the reactions involving EDPA. As summarized by the data in Table 4, these experiments revealed that the $\mathrm{Mb}(\mathrm{H} 64 \mathrm{~V}, \mathrm{~V} 68 \mathrm{~A})$ catalyzed cyclopropanation reaction with the acceptor-only carbene donor (EDA) proceeds with significantly higher rate (528-fold) and efficiency (140-fold higher TON) at room temperature than the corresponding reactions with EDPA at 50 ${ }^{\circ} \mathrm{C}$ (Entry 1 vs 2 ). A similar reactivity trend was observed for
Table 4. Reactivity Analysis of Bio- And Chemocatalytic Cyclopropanation Reactions Involving Different Diazo Reagents $^{a}$

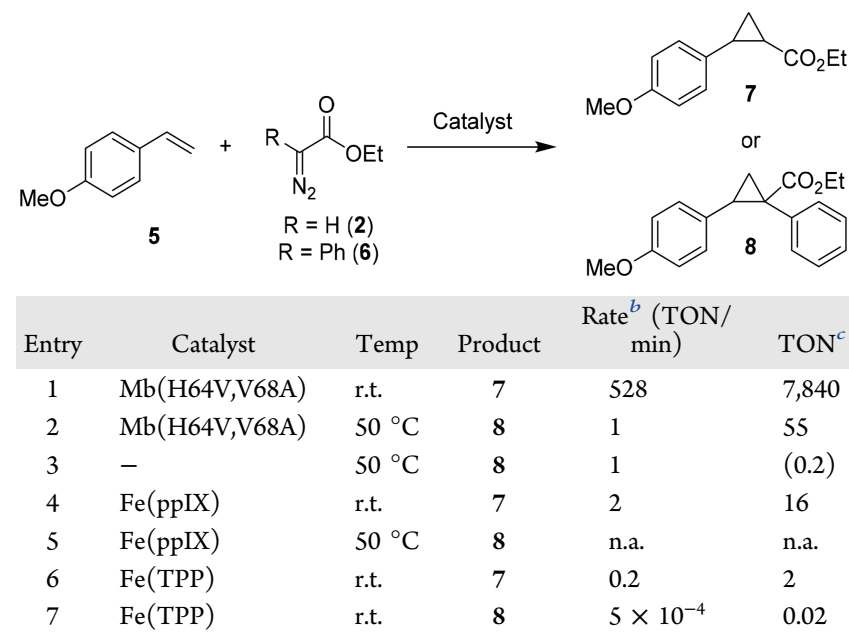

${ }^{a}$ Reaction conditions: $10 \mathrm{mM} \mathrm{5,} 10 \mathrm{mM}$ EDA (2) or EPDA (6), catalyst $(0.01 \mathrm{~mol} \% \mathrm{Mb}(\mathrm{H} 64 \mathrm{~V}, \mathrm{~V} 68 \mathrm{~A}) ; 2 \mathrm{~mol} \%$ hemin; $10 \mathrm{~mol} \%$ $\mathrm{Fe}(\mathrm{TPP})), 10 \mathrm{mM}$ sodium dithionite in $50 \mathrm{mM}$ potassium phosphate buffer ( $\mathrm{pH}$ 7) for $\mathrm{Mb}$ variant and hemin, or $\mathrm{CH}_{2} \mathrm{Cl}_{2}$ for $\mathrm{Fe}(\mathrm{TPP}$ ), at the indicated temperature. ${ }^{b}$ Initial rate over $1 \mathrm{~min}$ (EDA) and over 30 $\min (\mathrm{EDPA}){ }^{c}$ After $16 \mathrm{~h}$; n.a. = not active.

hemin and $\mathrm{Fe}(\mathrm{TPP})$, albeit both rates and catalytic turnovers (TON) were drastically reduced in both cases compared to the hemoprotein catalyst. Furthermore, unlike the latter, hemin yielded no cyclopropanation product in the reaction with EDPA at $50{ }^{\circ} \mathrm{C}$. These results are therefore consistent with the higher reactivity of the $\left[\mathrm{Fe}(\mathrm{Por})\left(\mathrm{CHCO}_{2} \mathrm{Et}\right)\right]$ vs $[\mathrm{Fe}($ Por $)(\mathrm{C}$ $\left.\left.(\mathrm{Ph}) \mathrm{CO}_{2} \mathrm{Et}\right)\right]$ intermediate as predicted by our computational analyses and previously observed using isolated IPC complexes. $^{31}$ As noted above, available experimental data ${ }^{31}$ demonstrate the reduced reactivity of $\left[\mathrm{Fe}(\mathrm{Por})\left(\mathrm{CPh}_{2}\right)\right]$ vs $\left[\mathrm{Fe}(\mathrm{Por})\left(\mathrm{C}(\mathrm{Ph}) \mathrm{CO}_{2} \mathrm{Et}\right)\right]$ in the cyclopropanation reaction.

Axial Ligand Effect. Previous studies on hemoproteincatalyzed cyclopropanation suggested an important role of the iron binding axial ligand toward affecting the reactivity of these biocatalysts. This effect can be evinced, for example, from the higher cyclopropanation activity exhibited by engineered myoglobins, which bear a histidine ligated heme, ${ }^{50,51}$ or by serine- and histidine-ligated $\mathrm{P} 450 \mathrm{~s},{ }^{47,48}$ compared to $\mathrm{P} 450$ featuring a native, cysteinate-ligated heme. ${ }^{46}$ Clear structurereactivity trends cannot be extracted from these reports, however, due to the use of different protein scaffolds (i.e., $\mathrm{Mb}$ vs P450s; different engineered variants), reaction 
conditions, and/or their investigation in whole-cell biotransformations, ${ }^{47,48}$ whose performance is affected by multiple factors such as the intracellular environment and protein expression levels. To better examine the impact of the axial ligand on hemoprotein-catalyzed cyclopropanation reactivity, two variants of $\mathrm{Mb}(\mathrm{H} 64 \mathrm{~V}, \mathrm{~V} 68 \mathrm{~A})$ were prepared in which the proximal histidine residue (His93) is substituted for cysteine (as in P450s) or phenylalanine, which is unable to coordinate the heme iron. After expression and isolation from E. coli, the proximal ligand variants $\mathrm{Mb}(\mathrm{H} 64 \mathrm{~V}, \mathrm{~V} 68 \mathrm{~A}, \mathrm{H} 93 \mathrm{C})$ and $\mathrm{Mb}$ (H64V,V68A,H93F) were found to exhibit distinct spectroscopic features, compared to each other and to $\mathrm{Mb}$ (H64V,V68A), with respect to their Soret and $Q$ bands in the ferric, ferrous and/or CO-bound form (Figure S1). These spectral differences reflect the different heme iron coordination environment present in these metalloproteins. Next, the catalytic rates of these biocatalysts for styrene cyclopropanation with EDA were determined via time course experiments. These experiments showed that the histidine-ligated $\mathrm{Mb}$ (H64V,V68A) catalyzes this reaction at a significantly higher rate $(995 \mathrm{TON} / \mathrm{min})$ than the cysteine-ligated counterpart (235 TON/min) or the $\mathrm{Mb}(\mathrm{H} 64 \mathrm{~V}, \mathrm{~V} 68 \mathrm{~A}, \mathrm{H} 93 \mathrm{~F})$ variant, which lacks metal coordination at the axial position $(210 \mathrm{TON} / \mathrm{min})$. Based on these results, the following order of reactivity was derived for the proximal ligand $\mathrm{Mb}$ variants: $\mathrm{Mb}(\mathrm{H} 64 \mathrm{~V}, \mathrm{~V} 68 \mathrm{~A})$ $\gg \mathrm{Mb}($ H64V,V68A,H93C) > Mb(H64V,V68A,H93F).

To investigate how these differences in enzymatic activity may correlate with the reactivity of the IPC intermediate, we compared the calculated energy profile for styrene cyclopropanation in the presence of $\left[\mathrm{Fe}(\mathrm{Por})\left(\mathrm{CHCO}_{2} \mathrm{Et}\right)\right]$ (reaction 2) with that involving $\left[\mathrm{Fe}(\mathrm{Por})\left(\mathrm{CHCO}_{2} \mathrm{Et}\right)(5-\right.$ MeIm)] (reaction 6), in which 5-methylimidazole (5-MeIm) mimics the axial His ligand (proximal His) present in myoglobin and $\mathrm{Mb}(\mathrm{H} 64 \mathrm{~V}, \mathrm{~V} 68 \mathrm{~A})$. These analyses show that the energy barrier $\left(\Delta G^{\ddagger}\right)$ for reaction 6 is lowered by $3.23 \mathrm{kcal} /$ mol compared to the heme mimic system lacking the axial ligand (reaction 2). This effect may arise from a more electrophilic carbene $\left(+0.01\right.$ e $Q_{C 1}$, Table S10) and a weaker $\mathrm{Fe}-\mathrm{C}$ bond (elongated by $0.05 \AA$, Table S9). Similarly to the imidazole ligand, a thiolate $\left(\mathrm{HS}^{-}\right)$ligand was also found to reduce the relative energy of the transition state $\left(\Delta G^{\ddagger}\right)$, as determined by analysis of the same reaction using $[\mathrm{Fe}$ (Por)$\left.\left(\mathrm{CHCO}_{2} \mathrm{Et}\right)\left(\mathrm{SH}^{-}\right)\right]$(reaction 7$)$. However, the $\Delta \Delta G^{\ddagger}$ value in this case is smaller $(1.19 \mathrm{kcal} / \mathrm{mol}$, Table 3$)$ compared to the imidazole axial ligand in reaction 6. The more favorable reaction rate associated with the neutral axial ligand may be a result of smaller energy cost of smaller geometry change (see, e.g., $\Delta R_{\mathrm{FeCl}}$ and $\Delta R_{\mathrm{ClC} 2}$ in Table 3) and smaller charge change (see, e.g., $Q_{\mathrm{CT}}$ and $\Delta Q_{\mathrm{Cl}}$ in Table 3 ) in the early transition states compared with the reactants. The relatively larger geometry change and charge change due to a negatively charged ligand probably comes from its relatively stronger trans effect and charge donation effect. ${ }^{86}$ Compared to the charged thiolate ligand $\left(\mathrm{RS}^{-}\right)$or no axial ligand, the imidazole ligand appears to exert a more favorable effect toward reducing the energy barrier not only for the cyclopropanation step, but also for the carbene formation step as reported recently. ${ }^{69}$ Such a synergistic effect may therefore lie at the basis of the excellent role of the histidine proximal ligand in modulating biocatalytic cyclopropanation reactivity, as evidenced by our results with the set of closely related, proximal ligand $\mathrm{Mb}$ variants. The beneficial effect of this histidine-ligated heme iron configuration is also apparent from the significantly higher catalytic activity and rate of $\mathrm{Mb}(\mathrm{H} 64 \mathrm{~V}, \mathrm{~V} 68 \mathrm{~A})$ compared to free hemin in the reactions described in Table 4, including those with the less reactive acceptor/donor diazo reagent (EDPA).

Effect of Porphyrin Substitution. Based on the results above, we envision that modification of the porphyrin ligand could provide an important, future opportunity for tuning the carbene transfer reactivity of hemoprotein-based catalysts, as suggested by the calculations on reactions 4 and 5 using authentic porphyrin substituents compared with nonsubstituted porphyrins in reactions 1 and 2. Supporting this notion, we recently reported how replacement of heme with an ironchlorin cofactor in myoglobin can confer enhanced cyclopropanation reactivity under aerobic conditions. ${ }^{87}$ The effect of porphyrin substituents on the enzymatic activity of hemoproteins is apparent also in the context of other reactions. ${ }^{8,89}$ Thus, to help guide future catalyst and reaction development, we set to examine the styrene cyclopropanation pathway using an electrondeficient iron-porphyrin carrying four electronwithdrawing cyano $(-\mathrm{CN})$ groups at the four meso positions (reaction 8), which based on the newly revealed cyclopropanation mechanism discussed above were expected to enhance carbene's electrophilicity. As anticipated, the carbene carbon was found to bear a more positive charge by $0.029 \mathrm{e}$ than the corresponding carbene atom in the unsubstituted porphyrin system of reaction 2 (Table S10). This change results in improved reactivity, as suggested by the reduced $\Delta G^{\ddagger}$ of $7.49 \mathrm{kcal} / \mathrm{mol}$ compared to $12.47 \mathrm{kcal} / \mathrm{mol}$ in reaction 2 . This ligand modification is thus expected to dramatically increase the rate of the cyclopropanation step. Figure 3-8 vs 3-2 indicates slightly smaller geometric changes in reactions 8 vs 2 . As this reaction has early transition state feature, smaller structural changes are associated with lower energy barriers, supporting the reduced $\Delta G^{\ddagger}$ of reaction 8 vs 2 .

Whereas these computational analyses provide insights into the steric (reactions 4 and 5) and electronic (reaction 8) effects of porphyrin substituents on cyclopropanation, previous work by Zhang and co-workers showed how the introduction of an hydrogen-bonding group (HBG) at the meso position (Figure 2-9) improves the performance of a Co-porphyrin catalyst in cyclopropanation reactions. ${ }^{66}$ This noncovalent interaction was found to decrease the carbene formation barrier in both $\mathrm{Co}^{6}{ }^{6}$ and $\mathrm{Fe}$-porphyrins ${ }^{69}$ due to carbene stabilization via the hydrogen bond between carbene's carboxylate moiety and the amide group of the HBG. Because the effect of HBG on the cyclopropanation pathway remains undefined, we studied the styrene cyclopropanation reaction involving the $\mathrm{CHCO}_{2} \mathrm{Et}$ complex of the HBG-substituted porphyrin, reaction 9. As shown in Table 3, the HBG group decreases the $\Delta G^{\ddagger}$ for the cyclopropanation by $0.57 \mathrm{kcal} / \mathrm{mol}$, which together with the $\Delta G^{\ddagger}$ reduction of $2.25 \mathrm{kcal} / \mathrm{mol}$ for the carbene formation step $^{69}$ may contribute to promoting catalytic performance as found experimentally for Co porphyrins. ${ }^{66}$ As the side chain of many natural amino acid residues (e.g., Ser, Thr, Asn, Tyr, etc.) can establish $\mathrm{H}$-bond interactions, these findings are relevant toward the future design and engineering of biocatalysts with improved cyclopropanation reactivity.

Upon investigation of the effect of various structural features (carbene substituent, proximal ligand, porphyrin substituents) on IPC mediated cyclopropanation pathways, we noted the existence of a good correlation between the Gibbs free energy of activation and the carbene carbon charge change $\left(R^{2}=0.93\right.$, Figure 4). This result further highlights the importance of the carbene electrophilicity in cyclopropanation catalyzed by heme- 


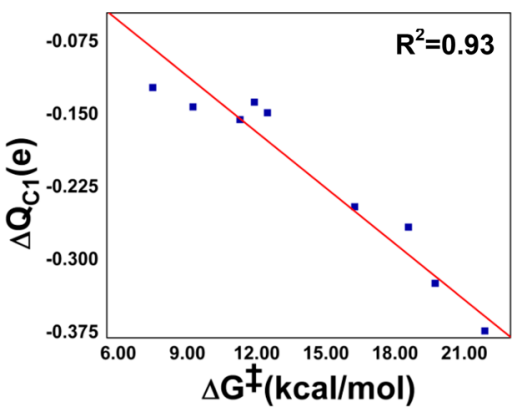

Figure 4. Plot of $\Delta Q_{C 1}$ vs $\Delta G^{\ddagger}$.

based carbene. As seen from Figure 4, smaller charge changes are associated with lower energy barriers, further supporting an early transition state character for the reactive intermediates in these reactions.

Overall Reactions and Comparison with Metal-Free Reactions. At high temperatures, diazo reagents can undergo thermal decomposition leading to cyclopropanation, ${ }^{90} \mathrm{C}-\mathrm{H}$ insertion, ${ }^{91}$ and $\mathrm{N}-\mathrm{H}$ insertion, ${ }^{92}$ in the absence of a metal catalyst. To compare and contrast the energy profiles of iron porphyrin-catalyzed vs metal-free cyclopropanation, we performed a systematic examination of four metal-involved pathways and two metal-free pathways using $\left[\mathrm{CHCO}_{2} \mathrm{Et}\right]$ as the carbene moiety (Scheme 2). Pathway I entails ironporphyrin catalyzed decomposition of EDA to form the IPC $\left[\mathrm{Fe}(\right.$ Por $\left.)\left(\mathrm{CHCO}_{2} \mathrm{Et}\right)\right]$, followed by the cyclopropanation step according to the most favorable mechanism as described earlier. Comparison of the computed $\Delta G^{\ddagger}$ for the cyclopropanation and carbene formation step as determined here and previously, ${ }^{69}$ respectively, suggests that the latter is the ratedetermining step (RDS) in this reaction pathway. Compared to pathway I, pathway II involves thermal decomposition of the IPC intermediate, followed by styrene cyclopropanation by the free carbene. As illustrated in Scheme 2, the carbene dissociation step becomes rate determining in this pathway, with a $15 \mathrm{kcal} / \mathrm{mol}$ higher energy barrier compared to the RDS in pathway I. In this case, although the triplet state of the free carbene is more favorable than the singlet state (Table S13), in agreement with previous calculations, ${ }^{91}$ the singlet carbene was considered for the pathway energy calculations because it is the most relevant species to react with singlet styrene to form the singlet cyclopropanation product, as done previously. ${ }^{91}$ In the case of metal-free reactions with diazo compound, two pathways were considered, namely pathway $\mathrm{V}$, which involves initial thermal decomposition of the diazo compound to liberate the free carbene followed by its reaction with styrene, and pathway VI, which involves a direct concerted cyclopropanation with concomitant release of $\mathrm{N}_{2}$. As shown in Scheme 2, the former pathway $(\mathrm{V})$ is relatively more favorable than pathway VI by $10.28 \mathrm{kcal} / \mathrm{mol}$, with carbene formation by thermal decomposition representing the RDS. Based on these analyses, pathways $\mathrm{I}$ and $\mathrm{V}$ are the preferred ones in the presence and in the absence of the metal catalyst, respectively, with the metal-assisted pathway I being more favorable by $20.91 \mathrm{kcal} / \mathrm{mol}$. Because preformed IPCs have been also investigated experimentally, ${ }^{31}$ pathways III and IV, which start from preformed IPCs and involve metal-assisted cyclopropanation and carbene dissociation/free carbene cyclopropanation, respectively, were also compared. As observed for pathway I vs II, the metal-assisted cyclopropanation pathway III is largely preferred over pathway IV by $28.43 \mathrm{kcal} / \mathrm{mol}$ (Scheme 2). As the temperature is raised from room temperature to $80{ }^{\circ} \mathrm{C}$, a condition applied to some reactions with preformed $\mathrm{IPC}^{31}$ and metal-free reactions with diazo compounds, ${ }^{91}$ the viable metalassisted pathways (I and III) feature increased energy barriers by $2-3 \mathrm{kcal} / \mathrm{mol}$, whereas the non-metal-assisted (thermal decomposition) pathways (V and IV) have reduced barriers by $\sim 2 \mathrm{kcal} / \mathrm{mol}$. These changes notwithstanding, the metalassisted pathways remain more favorable. In the presence of the donor-acceptor carbene, $\mathrm{C}(\mathrm{Ph}) \mathrm{CO}_{2} \mathrm{Et}$, the energy barrier difference for the RDS in metal-free pathway $\mathrm{V}$ vs the metalassisted pathway I is reduced by $4.30 \mathrm{kcal} / \mathrm{mol}$ at room temperature and further lowered by $3.04 \mathrm{kcal} / \mathrm{mol}$ at elevated temperature used for experimental studies of preformed IPC involved cyclopropanations. The contribution from the metalfree pathway is even further enhanced in the case of the donor-donor carbene, $\mathrm{C}(\mathrm{Ph})_{2}$ (Table 5). This trend is consistent with the improved performance of more electronrich donor-acceptor diazo compounds in metal-free reactions at high temperatures. ${ }^{90}$ Overall, these studies show that all reactions starting from either the diazo reagent or IPC feature the $\mathrm{Fe}^{\mathrm{II}}$-assisted process as the most favorable pathway, with the catalytic roles in helping both carbene formation and cyclopropanation. At the same time, the contribution from the metal-free pathway can increase as the temperature is raised and particularly so for carbenes bearing electron-donating substituents.

\section{CONCLUSIONS}

This work shows for the first time that the increasingly useful $\mathrm{C}=\mathrm{C}$ functionalization mediated by heme carbenes features a $\mathrm{Fe}^{\mathrm{II}}$-based, nonradical, concerted nonsynchronous mechanism, as supported by our DFT calculations and experimental mechanistic studies. This mechanism is thus distinct from the typical $\mathrm{Fe}^{\mathrm{IV}}$-based, radical, stepwise mechanism of hemedependent enzymes (i.e., cytochrome P450s). The present studies also provide key and novel insights into effects of the carbene substituent, porphyrin substituent, and the axial ligand on the activation barriers of IPC-mediated cyclopropanation and on the reactivity of hemoprotein-based cyclopropanation biocatalysts. In particular, our results demonstrate the importance of an electron-deficient carbene (acceptor-only > acceptor/donor $>$ donor/donor) as well as that of an imidazole axial ligand bound to the heme iron toward favoring cyclopropanation reactivity. Furthermore, our analyses predict the potentially beneficial effect of exploiting protein-mediated $\mathrm{H}$-bond interactions and/or electron-deficient porphyrin ligands toward further enhancing such reactivity, thereby providing valuable guidelines for future catalyst development efforts in the expanding area of hemoprotein-mediated carbene transfer chemistry. Incidentally, these studies demonstrate the feasibility of performing biocatalytic cyclopropanation reactions in the presence of poorly reactive donor-acceptor diazo reagents such as EDPA. This finding is relevant because biocatalytic carbene transfer reactions have so far been limited to acceptor-only diazo reagents and paves the way to future studies to explore the scope of this transformation. Finally, we report a first comparative analysis of metal-catalyzed vs thermally induced cyclopropanation, which further highlights the importance of heme-based catalysts and the critical role of forming electrophilic heme carbenes in these reactions. Overall, these studies are expected to facilitate the development of sustainable iron-porphyrin based (bio)catalysts for cyclo- 
Scheme 2. Cyclopropanation Pathways with and without Metal ${ }^{a}$

With Metal
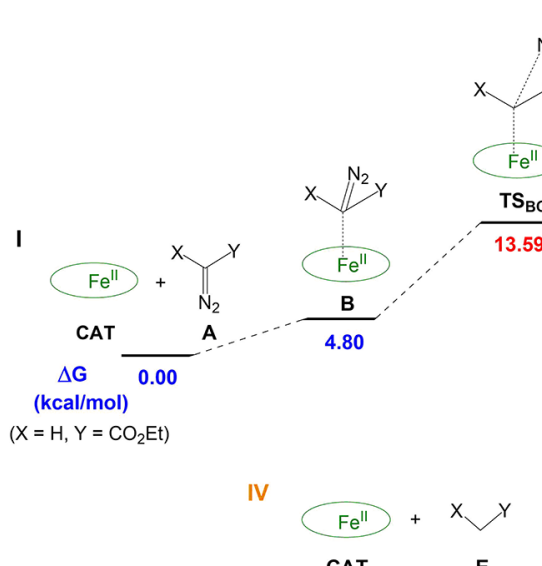

CAT

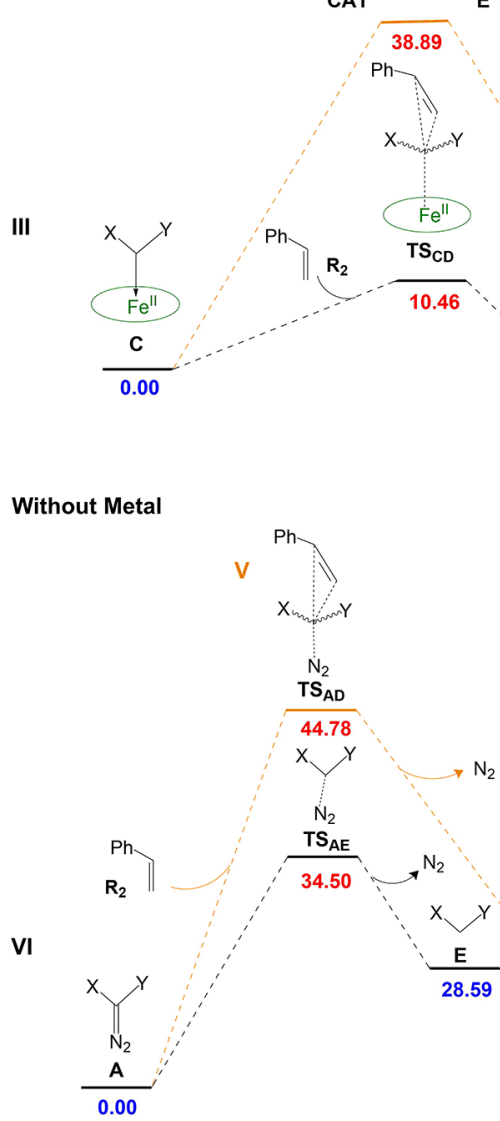

II

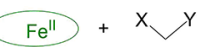

CAT E

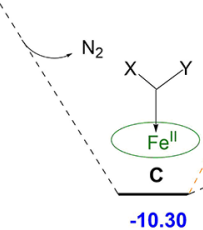

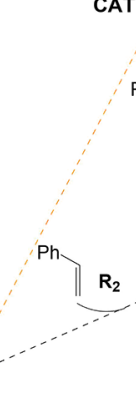

28.59

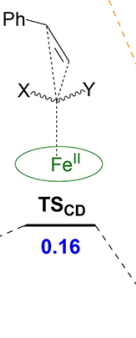

$\prod \mathbf{R}_{2}$
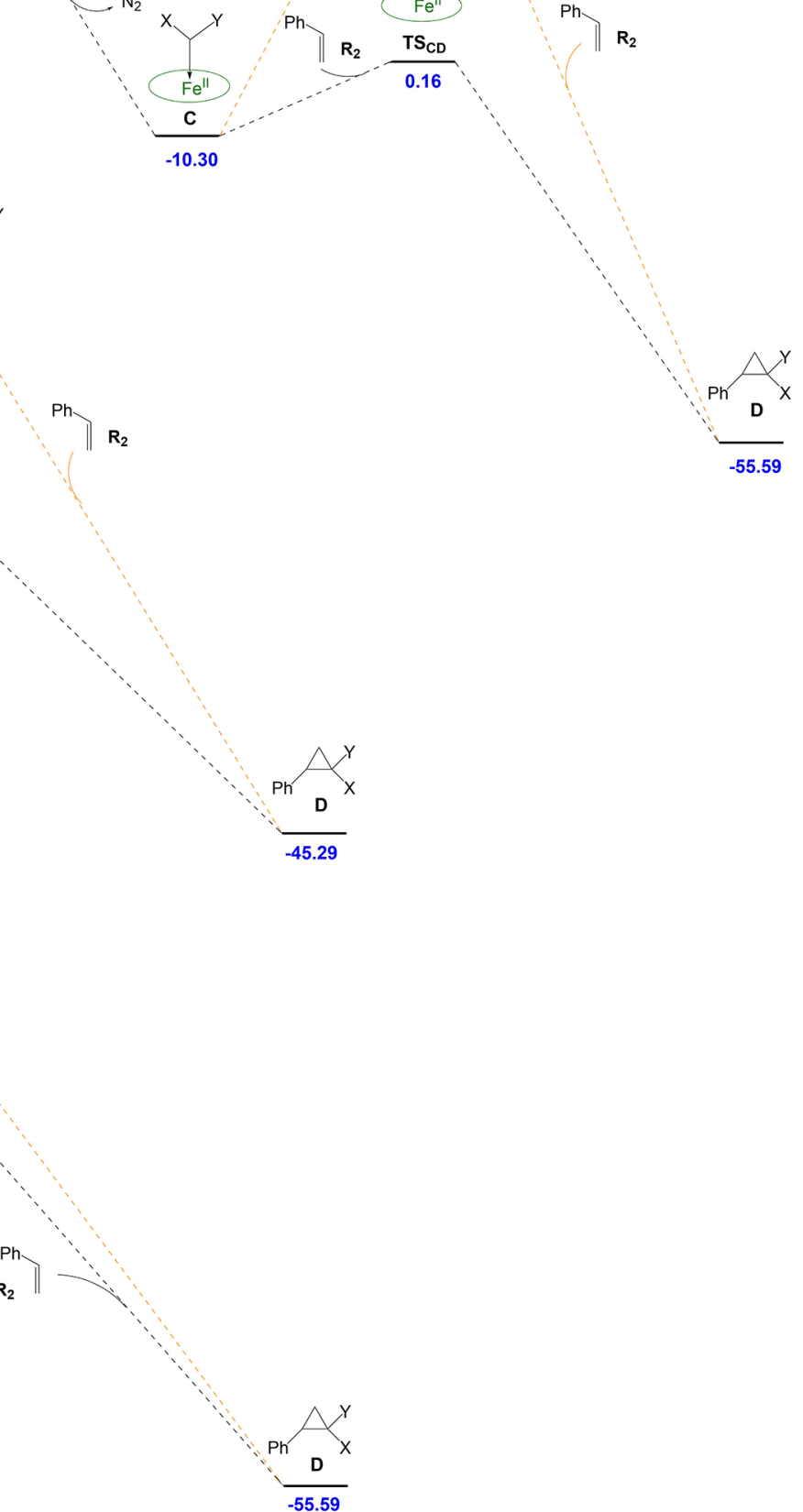

${ }^{a}$ The reported data are calculated at room temperature in protein environment.

propanations and, possibly, other important carbene-mediated transformations.

\section{EXPERIMENTAL PROCEDURES}

Computational Analyses. Nine styrene cyclopropanation reactions (see Scheme 1) and additional comparative reactions (see Scheme 2) were computationally investigated. All calculations were performed using Gaussian 09.93 All models investigated in this work were subject to full geometry optimizations without any symmetry constraints in the experimentally used solvents ${ }^{31}$ with the PCM method, ${ }^{94}$ i.e., benzene for reactions $1-5$ and $8-9$ and for reactions $6-7$, a dielectric constant of 4.0 was used to simulate the protein environment effect as done previously. ${ }^{95}$ The frequency analysis was used to verify the nature of the stationary points on respective potential energy surfaces and to provide zero-point energy corrected 
Table 5. Energies for Rate Determining Steps in Pathways I-IV

\begin{tabular}{|c|c|c|c|c|}
\hline $\mathrm{C}(\mathrm{X}) \mathrm{Y}$ & $T$ & From & Pathway & $\Delta G^{c}$ \\
\hline \multirow[t]{8}{*}{$\mathrm{X}=\mathrm{H}, \mathrm{Y}=\mathrm{CO}_{2} \mathrm{Et}^{a}$} & \multirow[t]{4}{*}{ r.t. } & \multirow[t]{2}{*}{ Diazo } & I & 13.59 \\
\hline & & & $\mathrm{V}$ & 34.50 \\
\hline & & \multirow[t]{2}{*}{ IPC } & III & 10.46 \\
\hline & & & IV & 38.89 \\
\hline & \multirow[t]{4}{*}{$80^{\circ} \mathrm{C}$} & \multirow[t]{2}{*}{ Diazo } & I & 15.78 \\
\hline & & & V & 33.90 \\
\hline & & \multirow[t]{2}{*}{ IPC } & III & 13.41 \\
\hline & & & IV & 36.22 \\
\hline \multirow[t]{8}{*}{$\mathrm{X}=\mathrm{Ph}, \mathrm{Y}=\mathrm{CO}_{2} \mathrm{Et}^{b}$} & \multirow[t]{4}{*}{ r.t. } & \multirow[t]{2}{*}{ Diazo } & I & 15.74 \\
\hline & & & $\mathrm{V}$ & 31.45 \\
\hline & & \multirow[t]{2}{*}{ IPC } & III & 16.87 \\
\hline & & & IV & 32.02 \\
\hline & \multirow[t]{4}{*}{$60{ }^{\circ} \mathrm{C}$} & \multirow[t]{2}{*}{ Diazo } & I & 17.73 \\
\hline & & & V & 31.30 \\
\hline & & \multirow[t]{2}{*}{ IPC } & III & 18.58 \\
\hline & & & IV & 30.15 \\
\hline \multirow[t]{8}{*}{$\mathrm{X}=\mathrm{Ph}, \mathrm{Y}=\mathrm{Ph}^{b}$} & \multirow[t]{4}{*}{ r.t. } & \multirow[t]{2}{*}{ Diazo } & I & 18.28 \\
\hline & & & $\mathrm{V}$ & 30.67 \\
\hline & & \multirow[t]{2}{*}{ IPC } & III & 18.20 \\
\hline & & & IV & 33.57 \\
\hline & \multirow[t]{4}{*}{$60{ }^{\circ} \mathrm{C}$} & \multirow[t]{2}{*}{ Diazo } & I & 20.20 \\
\hline & & & $\mathrm{V}$ & 30.51 \\
\hline & & \multirow[t]{2}{*}{ IPC } & III & 19.74 \\
\hline & & & IV & 31.80 \\
\hline
\end{tabular}

electronic energies $\left(E_{\mathrm{ZPE}}\right.$ 's), enthalpies $(H$ 's), and Gibbs free energies $(G$ 's) at $1 \mathrm{~atm}$ and experimental reaction temperatures, i.e., $333.15 \mathrm{~K}$ for reactions $1-5$ and $8-9$, and room temperature (r.t.) for reactions 6-7. The atomic charges and spin densities reported here are from the Natural Population Analysis (NPA) and Mulliken schemes respectively, as implemented in Gaussian 09. Relative Gibbs free energies and selected geometry, charge, and spin density results were discussed here, while all absolute values of electronic energies ( $E$ 's), zero-point energy corrected electronic energies $\left(E_{\mathrm{ZPE}}\right.$ 's), enthalpies $(H$ 's $)$, Gibbs free energies $(G$ 's), key geometric parameters, charges, spin densities, $3 \mathrm{D}$ structures and coordinates of optimized structures of the most favorable conformations and spin states as well as other details are in the Supporting Information.

All calculations were done using a range-separated hybrid DFT method with dispersion correction, $\omega \mathrm{B} 97 \mathrm{XD},{ }^{96}$ based on its excellent performance on heme carbenes and other catalytic systems from previous methodological studies. ${ }^{6-70,97}$ This $\omega \mathrm{B} 97 \mathrm{XD}$ method was found to yield accurate predictions of various experimental spectroscopic properties, structural features, and reactivity results of iron porphyrin carbenes. ${ }^{68-70}$ The basis set includes the effective core potential (ECP) basis $\mathrm{LanL} 2 \mathrm{DZ}^{98}$ for iron and the triple- $\zeta$ basis 6 $311 \mathrm{G}(\mathrm{d})$ for all other elements, which was found to provide accurate predictions of various experimental reaction properties of heme carbenes. $^{69,70}$ The use of a much larger $6-311++\mathrm{G}(2 \mathrm{~d}, 2 \mathrm{p})$ basis for all nonmetal atoms was found to yield similar results and thus further support the efficient use of the current basis set in reaction studies. ${ }^{70}$ The alternative use of an all-electron basis for the metal center was found here to result in qualitatively same conclusions of the geometric, electronic, and energetic features, and therefore supports the use of LanL2DZ basis set here, which may help direct comparisons with late transition metals in future studies, for which ECP basis is more readily available and commonly used. The details of these methodological studies are in the Supporting Information.

Among the nine reactions studied here, for reactions 2 and 6-9, singlet spin states are favored for both reactants and transition states, while in reactions 1 and $3-5$, because singlet is favored for reactants and triplet is favorable for transition states, they exhibit the so-called two state reactivity ${ }^{99-102}$ and there are minimum energy crossing points (MECPs) between these two spin states in these reactions. However, previous work ${ }^{99-102}$ also shows that these MECPs are of lower energy than the reaction transition states, i.e., they are not ratelimiting. So, the singlet reactants here after passing MECPs to become triplet reactants still need more energy to overcome the barriers of triplet transition states (the most favorable pathways here) to form products. Accordingly, the focus of this first computational mechanistic work in this area is on the rate-limiting reaction transition states, which is the most important part to understand the reactions and help future experimental work and catalyst design. Indeed, such transition states studied here well reproduced experimental reactivity results as described above.

The KIE calculations with tunneling effect correction $\left(\mathrm{KIE}_{\mathrm{W}}\right)$ were done using the following formulas reported recently: ${ }^{103}$

$$
\begin{aligned}
& \mathrm{KIE}_{\mathrm{E}}=\mathrm{e}^{\left(\left(-\Delta G_{\mathrm{H}}+\Delta G_{\mathrm{D}}\right) / R T\right)} \\
& \mathrm{KIE}_{\mathrm{W}}=\mathrm{KIE}_{\mathrm{E}} \times \frac{Q_{t \mathrm{H}}}{Q_{t \mathrm{D}}} \\
& \mathrm{Qt}(\text { Tunneling correction })=1+\frac{\left(\frac{h \nu}{k T}\right)^{2}}{24}
\end{aligned}
$$

where $h$ is Planck's constant, $v$ is the imaginary frequency of the transition state, $k$ is Boltzmann's constant, $T$ is temperature, and subscripts of $\mathrm{H}$ and $\mathrm{D}$ indicate hydrogen and deuterium, respectively.

General Procedures and Analytical Methods. All chemicals and reagents were purchased from commercial suppliers (SigmaAldrich, AlfaAeser, Cambridge Isotope Laboratories, Inc.) and used without any further purification, unless otherwise stated. 2-Diazo-2phenyl-acetate (6) was prepared following reported procedures. ${ }^{104}$ Authentic standards for $\mathbf{4}$ and 7 were prepared as described previously. ${ }^{51}{ }^{1} \mathrm{H},{ }^{13} \mathrm{C}$, and ${ }^{2} \mathrm{H}$ NMR spectra were measured on a Bruker DPX-400 instrument (operating at $400 \mathrm{MHz}$ for ${ }^{1} \mathrm{H}, 100 \mathrm{MHz}$ for ${ }^{13} \mathrm{C}$, and $60 \mathrm{MHz}$ for ${ }^{2} \mathrm{H}$ ) or a Bruker DPX-500 instrument (operating at $500 \mathrm{MHz}$ for ${ }^{1} \mathrm{H}$ and $125 \mathrm{MHz}$ for ${ }^{13} \mathrm{C}$ ). Tetramethylsilane (TMS) served as the internal standard (0 ppm) for ${ }^{1} \mathrm{H}$ NMR, $\mathrm{CDCl}_{3}$ was used as the internal standard (77.0 ppm) for ${ }^{13} \mathrm{C}$ NMR and for ${ }^{2} \mathrm{H}$ NMR (7.26 ppm). Gas chromatography (GC) analyses were carried out using a Shimadzu GC-2010 gas chromatograph equipped with an FID detector and a Chiral Cyclosil-B column $(30 \mathrm{~m} \times 0.25 \mathrm{~mm} \times 0.25 \mathrm{~mm}$ film). Separation method for cyclopropanation reactions: $1 \mathrm{~mL}$ injection, injector temp.: $200{ }^{\circ} \mathrm{C}$, detector temp.: $300{ }^{\circ} \mathrm{C}$. Gradient: column temperature set at $120^{\circ} \mathrm{C}$ for $3 \mathrm{~min}$, then to $150{ }^{\circ} \mathrm{C}$ at $0.8^{\circ} \mathrm{C} \mathrm{min}^{-1}$, then to $245^{\circ} \mathrm{C}$ at $25{ }^{\circ} \mathrm{C}$ $\mathrm{min}^{-1}$. Total run time: $46.30 \mathrm{~min}$. HPLC analyses were performed on a Shimadzu LC-2010A-HT equipped with a VisionHT $\mathrm{C}_{18}$ column and a UV-vis detector. Injection volume: $20 \mu \mathrm{L}$. Flow rate: $1 \mathrm{~mL} / \mathrm{min}$. Gradient: $30 \%$ acetonitrile (0.1\% TFA) in water ( $0.1 \%$ TFA) for 3 min, then increased to $90 \%$ over $58 \mathrm{~min}$.

Synthesis of cis- $\beta$-Deutero-styrene (1b). The cis- $\beta$-deutero-styrene was prepared in two steps from phenylacetylene according to the synthetic scheme shown in Figure S2. To a flame-dried $125 \mathrm{~mL}$ roundbottom flask was added phenylacetylene $(3.3 \mathrm{~mL}, 30.0 \mathrm{mmol}, 1.0$ equiv) and anhydrous THF $(20.0 \mathrm{~mL})$. The mixture was stirred in an ice-water bath $\left(0{ }^{\circ} \mathrm{C}\right)$ under argon pressure, and $n$-butyllithium $(2.5$ $\mathrm{M}$ in hexanes, $15.6 \mathrm{~mL}, 39.0 \mathrm{mmol}, 1.3$ equiv) was added dropwise via a gastight syringe over $15 \mathrm{~min}$. The reaction mixture was stirred at 0 ${ }^{\circ} \mathrm{C}$ for $1 \mathrm{~h}$, then $\mathrm{D}_{2} \mathrm{O}(3.0 \mathrm{~mL})$ was added slowly. The resulting mixture was stirred overnight at room temperature under argon pressure. The crude reaction mixture was passed through a pad of anhydrous $\mathrm{MgSO}_{4}$, using a medium-porosity fritted-glass funnel and rinsing with pentane (10 $\mathrm{mL}$, three times). The solvent was evaporated under reduced pressure to afford phenylacetylene- $d_{1}(2.93 \mathrm{~g}, 95 \%$ yield). ${ }^{1} \mathrm{H}$ NMR (500 MHz, $\left.\mathrm{CDCl}_{3}\right): \delta 7.49-7.47 \mathrm{ppm}(\mathrm{m}, 2 \mathrm{H})$, 7.34-7.28 ppm (m, 3H) ${ }^{13} \mathrm{C}$ NMR $\left(125 \mathrm{MHz}, \mathrm{CDCl}_{3}\right): 132.1 \mathrm{ppm}$, $128.8 \mathrm{ppm}, 128.3 \mathrm{ppm}, 122.2 \mathrm{ppm}, 83.3 \mathrm{ppm}(\mathrm{t}, J=7.5 \mathrm{~Hz}), 77.3 \mathrm{ppm}$ $(\mathrm{t}, \mathrm{J}=38.3 \mathrm{~Hz}$ ). GC-MS $m / z$ (\% relative intensity): 104 (57.4), 103 
(100), 78 (18.8), 77 (17.4). To a flame-dried $50 \mathrm{~mL}$ round-bottom flask was added zirconocene hydrochloride (Schwartz' reagent) (2.052 g, $7.93 \mathrm{mmol}, 1.1$ equiv), and the flask was purged with argon for 1 min. Anhydrous dichloromethane $(15 \mathrm{~mL})$ was added, and the flask was placed in an ice-water bath $\left(0{ }^{\circ} \mathrm{C}\right)$. Phenylacetylene- $d_{1}(0.744 \mathrm{~g}$, $0.80 \mathrm{~mL}, 7.2 \mathrm{mmol}, 1.0$ equiv) was added via syringe, and the reaction mixture was stirred at room temperature in the dark for $2 \mathrm{~h}$. Water $(1.0 \mathrm{~mL})$ was added, and the reaction mixture was stirred for an additional $2 \mathrm{~h}$. The resulting mixture was passed through a pad of anhydrous $\mathrm{MgSO}_{4}$, using a medium-porosity fritted-glass funnel and rinsing with pentane $(5 \mathrm{~mL}$, three times). The resulting suspension was passed through a silica gel pad using a medium-porosity frittedglass funnel and eluting with pentanes. The filtrate was concentrated under reduced pressure and an ice-water bath to afford cis- $\beta$-deuterostyrene (1b) (0.404 g, 53\% yield; >98:2 d.r. ( ${ }^{1} \mathrm{H}$ NMR) $)$ as a lightyellow oil. Note: to avoid substantial loss of the volatile product, a trace amount of solvent was not removed (ca. 5\% pentanes). ${ }^{1} \mathrm{H}$ NMR $\left(500 \mathrm{MHz}, \mathrm{CDCl}_{3}\right): \delta 7.43 \mathrm{ppm}(\mathrm{d}, J=7.5 \mathrm{~Hz}, 2 \mathrm{H}), 7.35 \mathrm{ppm}(\mathrm{t}, J=$ $7.4 \mathrm{~Hz}, 2 \mathrm{H}), 7.27 \mathrm{ppm}(\mathrm{m}, 1 \mathrm{H}), 6.73 \mathrm{ppm}(\mathrm{dt}, J=10.8 \mathrm{~Hz}, 2.1 \mathrm{~Hz}$, $1 \mathrm{H}), 5.25 \mathrm{ppm}(\mathrm{d}, J=10.9 \mathrm{~Hz}, 1 \mathrm{H}) .{ }^{13} \mathrm{C} \mathrm{NMR}\left(125 \mathrm{MHz}, \mathrm{CDCl}_{3}\right): \delta$ $137.6 \mathrm{ppm}, 136.8 \mathrm{ppm}, 128.5 \mathrm{ppm}, 127.8 \mathrm{ppm}, 126.2 \mathrm{ppm}, 113.7 \mathrm{ppm}$ $(\mathrm{t}, J=23.6 \mathrm{~Hz})$. GC-MS $\mathrm{m} / z$ (\% relative intensity): $105(100.0), 104$ (40.5), 79 (21.7), 78 (20.1).

Synthesis of ethyl 2-(4-methoxyphenyl)-1-phenylcyclopropanecarboxylate (8). An authentic standard for compound $\mathbf{8}$ was prepared via $\mathrm{Rh}$-catalyzed cyclopropanation as follows. To a flame-dried $10 \mathrm{~mL}$ round-bottom flask, equipped with a stir bar, were added 4-methoxystyrene (100 mg, $0.75 \mathrm{mmol}, 2.3$ eqiv.), $\mathrm{Rh}_{2}(\mathrm{OAc})_{4}(3 \mathrm{mg}, 6.4 \mu \mathrm{mol}, 2$ mol \%), and anhydrous DCM (3 mL) under argon. After that, a solution of ethyl 2-diazo-2-phenylacetate $(62 \mathrm{mg}, 0.32 \mathrm{mmol}, 1.0$ eqiv.) in anhydrous DCM $(1 \mathrm{~mL})$ was slowly added dropwise over a period of $30 \mathrm{~min}$. The resulting reaction mixture was stirred at room temperature for $16 \mathrm{~h}$. The solvent was removed under reduced pressure and the crude product purified via column chromatography on silica gel using $0-5 \%$ diethyl ether in pentanes to yield ethyl 2-(4methoxyphenyl)-1-phenylcyclopropanecarboxylate as a white crystalline solid ( $79 \mathrm{mg}, 0.27 \mathrm{mmol}, 85 \%$ yield). $R_{\mathrm{f}}=0.24$ (5\% diethyl ether in pentanes). ${ }^{1} \mathrm{H}$ NMR $\left(\mathrm{CDCl}_{3}, 500 \mathrm{MHz}\right): \delta 7.12\left(\mathrm{~s}, 3 \mathrm{H}, \mathrm{H}_{\mathrm{ar}}\right), 7.03$ $\left(\mathrm{s}, 2 \mathrm{H}, H_{\mathrm{ar}}\right), 6.69\left(\mathrm{~d}, 2 \mathrm{H}, H_{\mathrm{ar}}\right), 6.60\left(\mathrm{~d}, 2 \mathrm{H}, H_{\mathrm{ar}}\right), 4.18-4.08(\mathrm{~m}, 2 \mathrm{H}$, $\left.-\mathrm{CH}_{2} \mathrm{CH}_{3}\right), 3.69\left(\mathrm{~s}, 3 \mathrm{H},-\mathrm{OCH}_{3}\right), 3.05\left(\mathrm{~m}, 1 \mathrm{H}, \mathrm{H}_{\mathrm{Bn}}\right), 2.15(\mathrm{~m}, 1 \mathrm{H}$, $\left.\mathrm{CCCH}_{2}\right), 1.79\left(\mathrm{~m}, 1 \mathrm{H}, \mathrm{CCCH}_{2}\right), 1.18\left(\mathrm{t}, 3 \mathrm{H},-\mathrm{CH}_{2} \mathrm{CH}_{3}\right) .{ }^{13} \mathrm{C} \mathrm{NMR}$ $\left(\mathrm{CDCl}_{3}, 125 \mathrm{MHz}\right): \delta 174.0,158.2,135.1,132.1,129.1,128.6,127.7$, $126.9,113.3,61.3,55.2,37.4,32.6,20.4,14.3$. GC-MS $m / z$ (\% relative intensity): 297 (21.9), 296 (100.0), 267 (14.8), 251 (26.0), 250 (81.7), 249 (82.2), 224 (22.2), 223 (94.8), 222 (20.2), 221 (70.1).

Protein Expression. The $\mathrm{Mb}$ variants were expressed in E. coli BL21(DE3) or E. coli C41(DE3) cells as follows. After transformation, cells were grown in $\mathrm{TB}$ medium (ampicillin, $100 \mathrm{mg} \mathrm{L}^{-1}$ ) at $37^{\circ} \mathrm{C}$ $(200 \mathrm{rpm})$ until $\mathrm{OD}_{600}$ reached 0.6. Cells were then induced with 0.50 $\mathrm{mM}$ isopropyl- $\beta$-D-1-thiogalactopyranoside (IPTG) and $0.3 \mathrm{mM} \delta$ aminolevulinic acid (ALA). The cells were pelleted by centrifugation $\left(4,000 \mathrm{rpm}, 4^{\circ} \mathrm{C}, 20 \mathrm{~min}\right)$ and then resuspended in $20 \mathrm{~mL}$ of Ni-NTA Lysis Buffer ( $50 \mathrm{mM} \mathrm{KPi}, 250 \mathrm{mM} \mathrm{NaCl}, 10 \mathrm{mM}$ histidine, $\mathrm{pH} \mathrm{8.0)}$. Resuspended cells were frozen and stored at $-80{ }^{\circ} \mathrm{C}$ until purification. Cell suspensions were thawed at room temperature, lysed by sonication, and clarified by centrifugation $(14,000 \mathrm{rpm}, 20 \mathrm{~min}, 4$ $\left.{ }^{\circ} \mathrm{C}\right)$. The clarified lysate was transferred to a Ni-NTA column equilibrated with Ni-NTA Lysis Buffer. The resin was washed with 50 $\mathrm{mL}$ of Ni-NTA Lysis Buffer and then $50 \mathrm{~mL}$ of Ni-NTA Wash Buffer ( $50 \mathrm{mM} \mathrm{KPi}, 250 \mathrm{mM} \mathrm{NaCl}, 20 \mathrm{mM}$ histidine, $\mathrm{pH}$ 8.0). Proteins were eluted with Ni-NTA Elution Buffer ( $50 \mathrm{mM} \mathrm{KPi}, 250 \mathrm{mM} \mathrm{NaCl}, 250$ $\mathrm{mM}$ histidine, $\mathrm{pH}$ 7.0). After elution from the Ni-NTA column, the protein was buffer exchanged against $50 \mathrm{mM} \mathrm{KPi}$ buffer ( $\mathrm{pH} 7.0$ ) using $10 \mathrm{kDa}$ Centricon filters. Myoglobin concentration was determined using an extinction coefficient of $\varepsilon_{408}=157 \mathrm{mM}^{-1} \mathrm{~cm}^{-1}$ for ferric $\mathrm{Mb}(\mathrm{H} 64 \mathrm{~V}, \mathrm{~V} 68 \mathrm{~A}), \varepsilon_{406}=145 \mathrm{mM}^{-1} \mathrm{~cm}^{-1}$ for ferric $\mathrm{Mb}(\mathrm{H} 64 \mathrm{~V}, \mathrm{~V} 68 \mathrm{~A}, \mathrm{H} 93 \mathrm{~F})$, and $\varepsilon_{399}=118 \mathrm{mM}^{-1} \mathrm{~cm}^{-1}$ for ferric $\mathrm{Mb}(\mathrm{H} 64 \mathrm{~V}, \mathrm{~V} 68 \mathrm{~A}, \mathrm{H} 93 \mathrm{C})$, as determined using the hemochrome assay. ${ }^{105}$
Reactions with cis- $\beta$-Deutero-styrene. The $\mathrm{Mb}$ - and hemincatalyzed reactions were carried out at $2 \mathrm{~mL}$-scale using $60 \mu \mathrm{M}$ catalyst, $0.2 \mathrm{M}$ cis- $\beta$ - $d_{1}$-styrene (1b), $0.4 \mathrm{M}$ ethyl diazoacetate (EDA), and $10 \mathrm{mM}$ sodium dithionite. In a typical reaction, a solution containing sodium dithionite (100 $\mathrm{mM}$ stock solution) in potassium phosphate buffer (50 mM, pH 7, 10\% dimethylformamide (DMF)) was purged with argon for $3 \mathrm{~min}$ in a septum-capped vial. In a separate vial, a buffered solution containing myoglobin $(\mathrm{Mb})$ or hemin $(80 \mathrm{mM}$ in DMF) was carefully purged in tandem, and the two solutions were then mixed via cannula. Reactions were initiated by the addition of cis$\beta$ - $d_{1}$-styrene ( $42.1 \mathrm{mg}, 0.400 \mathrm{mmol}, 1.0$ equiv), followed by addition of EDA $(84.0 \mu \mathrm{L}, 0.800 \mathrm{mmol}, 2.0$ equiv) with a syringe. The reaction was stirred at room temperature under argon pressure for $16 \mathrm{~h}$. The reaction product was extracted with dichloromethane $(2 \mathrm{~mL}$, three times), and the organic layers were collected and dried over anhydrous sodium sulfate. The organic solvent was removed by rotary evaporation, and the crude trans-2-phenyl-1-ethyl carboxylate cyclopropane product $(\mathbf{2} \mathbf{a} / \mathbf{b})$ was purified via flash column chromatography using silica gel and 5\% EtOAc/hexanes as the eluent to afford the desired product as a clear, colorless oil. For the $\mathrm{Fe}$ (TPP)- and Co(TPP)-catalyzed reactions, cis- $\beta$ - $d_{1}$-styrene $(50.0 \mathrm{mg}, 0.475 \mathrm{mmol}$, 1.0 equiv) and either $\mathrm{Fe}(\mathrm{TPP}) \mathrm{Cl}(16.7 \mathrm{mg}, 0.024 \mathrm{mmol}, 0.05$ equiv) or Co(TPP) ( $16.1 \mathrm{mg}, 0.024 \mathrm{mmol}, 0.05$ equiv) was added to a flamedried $50 \mathrm{~mL}$ two-neck round-bottom flask. The flask was purged with argon for $1 \mathrm{~min}$, and anhydrous dichloromethane $(15 \mathrm{~mL})$ was added. Ethyl-2-diazoacetate $(75.0 \mu \mathrm{L}, 0.713 \mathrm{mmol}, 1.5$ equiv) was dissolved in anhydrous dichloromethane $(3 \mathrm{~mL})$, and was added slowly to the reaction mixture over $4 \mathrm{~h}$. The reaction flask was heated to a reflux ( 40 ${ }^{\circ} \mathrm{C}$ ) under an argon atmosphere. After $16 \mathrm{~h}$, the crude reaction mixture was concentrated under reduced pressure, and the crude trans-2phenyl-1-ethyl carboxylate cyclopropane product $(\mathbf{2} \mathbf{a} / \mathbf{b})$ was purified as described above. Isolated yields were $2.4 \mathrm{mg}(3.1 \%)$ for $\mathrm{WT} \mathrm{Mb}$, $37.0 \mathrm{mg}(48.3 \%)$ for $\mathrm{Mb}(\mathrm{H} 64 \mathrm{~V}, \mathrm{~V} 68 \mathrm{~A}), 19.1 \mathrm{mg}(24.9 \%)$ for hemin, $12.8 \mathrm{mg}(14.1 \%)$ for $\mathrm{Fe}(\mathrm{TPP})$, and $4.5 \mathrm{mg}$ (5.0\%) for $\mathrm{Co}$ (TPP). Characterization data for enantiopure 2a (from $\mathrm{Mb}(\mathrm{H} 64 \mathrm{~V}, \mathrm{~V} 6 \mathrm{~A})$ reaction). ${ }^{1} \mathrm{H} \mathrm{NMR}\left(400 \mathrm{MHz}, \mathrm{CDCl}_{3}\right): \delta 7.30(\mathrm{t}, J=7.2 \mathrm{~Hz}, 2 \mathrm{H})$, $7.22(\mathrm{t}, J=7.2 \mathrm{~Hz}, 1 \mathrm{H}), 7.11(\mathrm{~d}, J=7.2 \mathrm{~Hz}, 2 \mathrm{H}), 4.20(\mathrm{q}, J=14.4 \mathrm{~Hz}$, $7.2 \mathrm{~Hz}, 2 \mathrm{H}), 2.53(\mathrm{dd}, J=9.2 \mathrm{~Hz}, 4.0 \mathrm{~Hz}, 1 \mathrm{H}), 1.91$ (t (=dd), $J=4.0$ $\mathrm{Hz}, 1 \mathrm{H}), 1.61(\mathrm{dd}, J=8.9 \mathrm{~Hz}, 5.2 \mathrm{~Hz}, 1 \mathrm{H}), 1.30(\mathrm{t}, J=7.2 \mathrm{~Hz}, 3 \mathrm{H})$ ppm. ${ }^{13} \mathrm{C}$ NMR $\left(100 \mathrm{MHz}, \mathrm{CDCl}_{3}\right): \delta 173.2,140.0,128.3,126.3$, 126.0, 60.5, 25.9, 23.9, $16.8(\mathrm{t}, J=25 \mathrm{~Hz}), 14.1 \mathrm{ppm} .{ }^{2} \mathrm{H}$ NMR $(60$ $\left.\mathrm{MHz}, \mathrm{CDCl}_{3}\right): \delta 1.32 \mathrm{ppm}(\mathrm{s}, 1 \mathrm{H})$. GC-MS $\mathrm{m} / \mathrm{z}$ (\% relative intensity): 191 (35.3), 146 (31.7), 145 (26.7), 135 (24.7), 118 (100.0), 117 (31.2), 116 (62.0), 92 (20.5). The ${ }^{1} \mathrm{H}$ NMR and ${ }^{2} \mathrm{H}$ NMR spectrum of the isolated $\mathrm{Co}(\mathrm{TPP})$-catalyzed reaction product shows a 1.5:1 mixture of $\mathbf{3 a}$ and $\mathbf{3 b}$ diastereomers $\left({ }^{2} \mathrm{H}\right.$ NMR $(60 \mathrm{MHz}$, $\left.\left.\mathrm{CDCl}_{3}\right): \delta 1.72 \mathrm{ppm}(\mathrm{s}, 0.66 \mathrm{H}), 1.32 \mathrm{ppm}(\mathrm{s}, 1 \mathrm{H})\right)$. In contrast, the ${ }^{1} \mathrm{H}$ NMR and ${ }^{2} \mathrm{H}$ NMR spectra of the isolated products from the reactions with $\mathrm{Mb}$ and $\mathrm{Fe}(\mathrm{TPP}$ ) shows a single diastereomer (3a) (see spectra in Supporting Information).

Radical Spin Trap Experiments. The $\mathrm{Mb}$ - and hemin-catalyzed reactions were carried out on a $400 \mu \mathrm{L}$ scale using $20 \mu \mathrm{M}$ catalyst, 10 $\mathrm{mM}$ styrene, $20 \mathrm{mM}$ ethyl diazoacetate (EDA), with or without 100 $\mathrm{mM} 5$,5-dimethyl-1-pyrroline- $N$-oxide (DMPO), and $10 \mathrm{mM}$ sodium dithionite. In a typical reaction, a solution containing sodium dithionite (100 $\mathrm{mM}$ stock solution) in potassium phosphate buffer (50 mM, pH 7, 10\% dimethylformamide (DMF)) was purged with argon for $3 \mathrm{~min}$ in a septum-capped vial. In a separate vial, a buffered solution containing myoglobin $(\mathrm{Mb})$ or hemin $(80 \mathrm{mM}$ in DMF) was carefully purged in tandem, and the two solutions were then mixed together via cannula. Reactions were initiated by the addition of styrene ( $40 \mu \mathrm{L}, 100 \mathrm{mM}$ stock in DMF, 1.0 equiv), followed by the addition of DMPO ( $40 \mu \mathrm{L}, 1 \mathrm{M}$ stock in DMF, 10.0 equiv), and EDA (40 $\mu \mathrm{L}, 200 \mathrm{mM}$ stock in DMF, 2.0 equiv) with a syringe. The reaction was stirred at room temperature, under argon pressure for 16 h. For product analysis, internal standard $(20 \mu \mathrm{L}$ of benzodioxole at $100 \mathrm{mM}$ in ethanol) was added to the reaction mixture, followed by extraction with dichloromethane $(400 \mu \mathrm{L})$, and analysis by GC-FID. For the Co(TPP)-catalyzed reaction, Co(TPP) $(8.1 \mathrm{mg}, 0.012 \mathrm{mmol}$, 0.05 equiv), styrene $(25.0 \mathrm{mg}, 0.240 \mathrm{mmol}, 1.0$ equiv), and $\mathrm{DMPO}$ 
(0.272g, $2.40 \mathrm{mmol}, 10.0$ equiv) were added to a flame-dried $25 \mathrm{~mL}$ two-neck round-bottom flask. The flask was purged with argon for 1 min, and anhydrous dichloromethane $(3 \mathrm{~mL})$ was added. Ethyl-2diazoacetate $(38.0 \mu \mathrm{L}, 0.360 \mathrm{mmol}, 1.5$ equiv) was dissolved in anhydrous dichloromethane $(2 \mathrm{~mL})$, and was added slowly to the reaction mixture over $4 \mathrm{~h}$. The flask was heated to a reflux $\left(40{ }^{\circ} \mathrm{C}\right)$ under argon atmosphere. After $16 \mathrm{~h}$, internal standard $(20 \mu \mathrm{L}$ of benzodioxole at $100 \mathrm{mM}$ in ethanol) was added to a $400 \mu \mathrm{L}$ aliquot of the reaction mixture. The mixture was washed with $400 \mu \mathrm{L}$ of saturated $\mathrm{NaCl}$ solution, followed by centrifugation $(14,000 \mathrm{rpm})$ and analysis of the organic layer by GC-FID.

Reactivity studies with EDA vs EDPA. The hemin- and Mbcatalyzed reactions were carried out at a $400 \mu \mathrm{L}$-scale using $200 \mu \mathrm{M}$ hemin or $1 \mu \mathrm{M} \mathrm{Mb}(\mathrm{H} 64 \mathrm{~V}, \mathrm{~V} 68 \mathrm{~A}), 10 \mathrm{mM}$ 4-methoxy-styrene, $10 \mathrm{mM}$ diazo compound (ethyl 2-diazoacetate (EDA) or ethyl 2-diazo-2phenylacetate (EDPA)), and $10 \mathrm{mM}$ sodium dithionite in potassium phosphate buffer $(50 \mathrm{mM}, \mathrm{pH} 7.0)$. In a typical procedure, a buffered solution containing sodium dithionite was degassed by bubbling argon into the mixture for $3 \mathrm{~min}$ in a sealed vial. A solution containing the catalyst (hemin in DMSO; $\mathrm{Mb}(\mathrm{H} 64 \mathrm{~V}, \mathrm{~V} 68 \mathrm{~A})$ in buffer) was carefully degassed in a separate vial. The two solutions were then mixed together via cannula. Reactions were initiated by addition of $10 \mu \mathrm{L}$ of styrene (from a $0.4 \mathrm{M}$ stock solution in ethanol), followed by the addition of $10 \mu \mathrm{L}$ of diazo compound (from a $0.4 \mathrm{M}$ stock solution in ethanol) with a syringe. The reaction mixture was stirred at room temperature (ethyl 2-diazoacetate) or $50{ }^{\circ} \mathrm{C}$ (ethyl 2-diazo-2phenylacetate) before quenching with $100 \mu \mathrm{L}$ of $2 \mathrm{~N} \mathrm{HCl}$. Product formation ( 7 or 8 ) was monitored at different time points over 180 $\mathrm{min}$ and then after $16 \mathrm{~h}$. The EDA reactions were analyzed by adding $20 \mu \mathrm{L}$ of internal standard (benzodioxole, $50 \mathrm{mM}$ in ethanol) to the reaction mixture, followed by extraction with $400 \mu \mathrm{L}$ of DCM, and analysis by GC-FID. The EDPA reactions were extracted with $400 \mu \mathrm{L}$ of DCM, the organic layer was removed via evaporation and the residue was dissolved in $300 \mu \mathrm{L}$ methanol and $20 \mu \mathrm{L}$ DMSO, followed by HPLC analysis. Control experiments with no catalyst showed negligible background (thermally induced) formation of 8 at $50{ }^{\circ} \mathrm{C}$, this amount accounting for $<0.5 \%$ of the product formed in the presence of $\mathrm{Mb}(\mathrm{H} 64 \mathrm{~V}, \mathrm{~V} 68 \mathrm{~A})$. The $\mathrm{Fe}(\mathrm{TPP})$-catalyzed reactions were carried out on a $400 \mu \mathrm{L}$-scale using $1 \mathrm{mM} \mathrm{Fe}(\mathrm{TPP}), 10 \mathrm{mM}$ sodium dithionite, $10 \mathrm{mM}$ styrene, and $10 \mathrm{mM}$ diazo compound (ethyl 2diazoacetate or ethyl 2-diazo-2-phenylacetate) in anhydrous DCM. In a typical procedure, $40 \mu \mathrm{L} \mathrm{Fe}$ (TPP) (from a $2.5 \mathrm{mM}$ stock solution in anhydrous DCM) were added to a flame-dried, sealed vial under argon and purged with argon for $3 \mathrm{~min}$. Subsequently, $380 \mu \mathrm{L}$ of anhydrous DCM were added, and reactions were initiated by addition of $10 \mu \mathrm{L}$ of styrene (from a $0.4 \mathrm{M}$ stock solution in ethanol), followed by the addition of $10 \mu \mathrm{L}$ of diazo compound (from a $0.4 \mathrm{M}$ stock solution in ethanol) with a syringe. The reaction mixture was stirred at room temperature and product formation was monitored at different time points over $180 \mathrm{~min}$ and then after $16 \mathrm{~h}$. The EDA reactions were immediately analyzed by GC-FID after adding $20 \mu \mathrm{L}$ of internal standard (benzodioxole, $50 \mathrm{mM}$ in ethanol). The EDPA reactions were stopped by rapidly removing the organic layer under high vacuum $(<1-2 \mathrm{~min})$, after which the residue was dissolved in $300 \mu \mathrm{L}$ of methanol and $20 \mu \mathrm{L}$ of DMSO and analyzed by HPLC. Rates and catalytic turnovers were determined by means calibration curves prepared using authentic standards of 7 and 8 prepared synthetically.

Reactions with Proximal Ligand Mb Variants. Reactions were carried out on a $400 \mu \mathrm{L}$ scale using $1 \mu \mathrm{M} \mathrm{Mb}(\mathrm{H} 64 \mathrm{~V}, \mathrm{~V} 68 \mathrm{~A})$, or $5 \mu \mathrm{M}$ for $(\mathrm{Mb}(\mathrm{H} 64 \mathrm{~V}, \mathrm{~V} 68 \mathrm{~A}, \mathrm{H} 93 \mathrm{C})$ and $(\mathrm{Mb}(\mathrm{H} 64 \mathrm{~V}, \mathrm{~V} 68 \mathrm{~A}, \mathrm{H} 93 \mathrm{~F}), 20 \mathrm{mM}$ styrene, $0.5-80 \mathrm{mM}$ ethyl diazoacetate (EDA), and $10 \mathrm{mM}$ sodium dithionite. In a typical reaction, a solution containing sodium dithionite (100 $\mathrm{mM}$ stock solution) in potassium phosphate buffer $(50 \mathrm{mM}, \mathrm{pH} 7,20 \% \mathrm{MeOH})$ was purged with argon for $3 \mathrm{~min}$ in a septum-capped vial. In a separate vial, a buffered solution containing the $\mathrm{Mb}$ variant was carefully purged in tandem, and the two solutions were then mixed together via cannula. Reactions were initiated by the addition of styrene $(10 \mu \mathrm{L}, 800 \mathrm{mM}$ stock solution in $\mathrm{EtOH})$, followed by the addition EDA ( $80-800 \mathrm{mM}$ stock solutions in EtOH) with a syringe. The reactions were stirred at room temperature under argon pressure for $30 \mathrm{~s}$, and then immediately quenched with $100 \mu \mathrm{L} \mathrm{HCl} \mathrm{(2}$ $\mathrm{N})$ via syringe. The reactions were analyzed by GC-FID as described above. The reported rates refer to the initial rates of product formation measured at near-saturation conditions ( $80 \mathrm{mM}$ EDA).

\section{ASSOCIATED CONTENT}

\section{Supporting Information}

The Supporting Information is available free of charge on the ACS Publications website at DOI: 10.1021/jacs.7b09171.

Computational details of methods, absolute energies, key geometric parameters, charges, spin densities, 3D structures and coordinates of optimized structures of the most favorable conformations and spin states, as well as experimental UV-vis spectra, and NMR spectra (PDF)

\section{AUTHOR INFORMATION}

\section{Corresponding Authors}

*yong.zhang@stevens.edu

*rfasan@ur.rochester.edu

ORCID

Antonio Tinoco: 0000-0003-3960-9457

Rudi Fasan: 0000-0003-4636-9578

Yong Zhang: 0000-0001-7207-6416

Notes

The authors declare no competing financial interest.

\section{ACKNOWLEDGMENTS}

This work was supported by the U.S. National Science Foundation (NSF) grant CHE-1300912 awarded to Y.Z. and by the U.S. National Institute of Health (NIH) grant GM098628 awarded to R.F. A.T. acknowledges support from the Ford Foundation Graduate Fellowship Program. MS instrumentation at the University of Rochester was supported by the NSF grant CHE-0946653.

\section{REFERENCES}

(1) Talele, T. T. J. Med. Chem. 2016, 59, 8712-8756.

(2) Reichelt, A.; Martin, S. F. Acc. Chem. Res. 2006, 39, 433-442.

(3) Gnad, F.; Reiser, O. Chem. Rev. 2003, 103, 1603-1624.

(4) Wessjohann, L. A.; Brandt, W.; Thiemann, T. Chem. Rev. 2003, $103,1625-1648$

(5) Donaldson, W. A. Tetrahedron 2001, 57, 8589-8627.

(6) Doyle, M. P.; Forbes, D. C. Chem. Rev. 1998, 98, 911-936.

(7) Lebel, H.; Marcoux, J.-F.; Molinaro, C.; Charette, A. B. Chem. Rev. 2003, 103, 977-1050.

(8) Pellissier, H. Tetrahedron 2008, 64, 7041-7095.

(9) Ebner, C.; Carreira, E. M. Chem. Rev. 2017, 117, 11651-11679.

(10) Maxwell, J. L.; Brown, K. C.; Bartley, D. W.; Kodadek, T. Science 1992, 256, 1544-1547.

(11) Bartley, D. W.; Kodadek, T. J. Am. Chem. Soc. 1993, 115, 16561660.

(12) Niino, T.; Toganoh, M.; Andrioletti, B.; Furuta, H. Chem. Commun. 2006, 4335-4337.

(13) Gorin, C. F.; Beh, E. S.; Bui, Q. M.; Dick, G. R.; Kanan, M. W. J. Am. Chem. Soc. 2013, 135, 11257-11265.

(14) Sreenilayam, G.; Moore, E. J.; Steck, V.; Fasan, R. Adv. Synth. Catal. 2017, 359, 2076-2089.

(15) Galardon, E.; Maux, P. L.; Toupet, L.; Simonneaux, G. Organometallics 1998, 17, 565-569.

(16) Che, C. M.; Huang, J. S.; Lee, F. W.; Li, Y.; Lai, T. S.; Kwong, H. L.; Teng, P. F.; Lee, W. S.; Lo, W. C.; Peng, S. M.; Zhou, Z. Y. J. Am. Chem. Soc. 2001, 123, 4119-4129. 
(17) Deng, Q.-H.; Chen, J.; Huang, J.-S.; Chui, S. S.-Y.; Zhu, N.; Li, G.-Y.; Che, C.-M. Chem. - Eur. J. 2009, 15, 10707-10712.

(18) Ho, C.-M.; Zhang, J.-L.; Zhou, C.-Y.; Chan, O.-Y.; Yan, J. J.; Zhang, F.-Y.; Huang, J.-S.; Che, C.-M. J. Am. Chem. Soc. 2010, 132, 1886-1894.

(19) Raoul, N.; Gallo, E.; Rose, E. J. Porphyrins Phthalocyanines 2011, $15,602-611$.

(20) Chan, K.-H.; Guan, X.; Lo, V. K.-Y.; Che, C.-M. Angew. Chem., Int. Ed. 2014, 53, 2982-2987.

(21) Wolf, M. W.; Vargas, D. A.; Lehnert, N. Inorg. Chem. 2017, 56, $5623-5635$.

(22) Smith, D. A.; Woo, L. K. Organometallics 1992, 11, 2344-2346.

(23) Smith, D. A.; Reynolds, D. N.; Woo, L. K. J. Am. Chem. Soc. 1993, 115, 2511-2513.

(24) Djukic, J.-P.; Smith, D. A.; Young, V. G., Jr.; Woo, L. K. Organometallics 1994, 13, 3020-3026.

(25) Li, Y.; Huang, J. S.; Zhou, Z. Y.; Che, C. M. J. Am. Chem. Soc. 2001, 123, 4843-4844.

(26) Wang, J.-C.; Xu, Z.-J.; Guo, Z.; Deng, Q.-H.; Zhou, C.-Y.; Wan, X.-L.; Che, C.-M. Chem. Commun. 2012, 48, 4299-4301.

(27) Anding, B. J.; Ellern, A.; Woo, L. K. Organometallics 2012, 31, $3628-3635$.

(28) Key, H. M.; Dydio, P.; Liu, Z.; Rha, J. Y.; Nazarenko, A.; Seyedkazemi, V.; Clark, D. S.; Hartwig, J. F. ACS Cent. Sci. 2017, 3, 302-308.

(29) Wolf, J. R.; Hamaker, C. G.; Djukic, J. P.; Kodadek, T.; Woo, L. K. J. Am. Chem. Soc. 1995, 117, 9194-9199.

(30) Hamaker, C. G.; Mirafzal, G. A.; Woo, L. K. Organometallics 2001, 20, 5171-5176.

(31) Li, Y.; Huang, J. S.; Zhou, Z. Y.; Che, C. M.; You, X. Z. J. Am. Chem. Soc. 2002, 124, 13185-13193.

(32) Lai, T. S.; Chan, F. Y.; So, P. K.; Ma, D. L.; Wong, K. Y.; Che, C. M. Dalton Trans. 2006, 4845-4851.

(33) Carminati, D. M.; Intrieri, D.; Caselli, A.; Le Gac, S.; Boitrel, B.; Toma, L.; Legnani, L.; Gallo, E. Chem. - Eur. J. 2016, 22, 1359913612.

(34) Morandi, B.; Dolva, A.; Carreira, E. M. Org. Lett. 2012, 14, $2162-2163$

(35) Morandi, B.; Carreira, E. M. Science 2012, 335, 1471-1474.

(36) Nicolas, I.; Maux, P. L.; Simonneaux, G. Tetrahedron Lett. 2008, 49, 5793-5795.

(37) Gross, Z.; Galili, N.; Simkhovich, L. Tetrahedron Lett. 1999, 40, $1571-1574$

(38) Chen, Y.; Ruppel, J. V.; Zhang, X. P. J. Am. Chem. Soc. 2007, 129, 12074-12075.

(39) Chen, Y.; Zhang, X. P. J. Org. Chem. 2007, 72, 5931-5934.

(40) Zhu, S.; Ruppel, J. V.; Lu, H.; Wojtas, L.; Zhang, X. P. J. Am. Chem. Soc. 2008, 130, 5042-5043.

(41) Zhu, S.; Perman, J. A.; Zhang, X. P. Angew. Chem., Int. Ed. 2008, 47, 8460-8463.

(42) Penoni, A.; Wanke, R.; Tollari, S.; Gallo, E.; Musella, D.; Ragaini, F.; Demartin, F.; Cenini, S. Eur. J. Inorg. Chem. 2003, 2003, $1452-1460$

(43) Fantauzzi, S.; Gallo, E.; Rose, E.; Raoul, N.; Caselli, A.; Issa, S.; Ragaini, F.; Cenini, S. Organometallics 2008, 27, 6143-6151.

(44) Reddy, A. R.; Hao, F.; Wu, K.; Zhou, C.-Y.; Che, C.-M. Angew. Chem., Int. Ed. 2016, 55, 1810-1815.

(45) Xu, X.; Zhu, S.; Cui, X.; Wojtas, L.; Zhang, X. P. Angew. Chem., Int. Ed. 2013, 52, 11857-11861.

(46) Coelho, P. S.; Brustad, E. M.; Kannan, A.; Arnold, F. H. Science 2013, 339, 307-310.

(47) Coelho, P. S.; Wang, Z. J.; Ener, M. E.; Baril, S. A.; Kannan, A.; Arnold, F. H.; Brustad, E. M. Nat. Chem. Biol. 2013, 9, 485-487.

(48) Wang, Z. J.; Renata, H.; Peck, N. E.; Farwell, C. C.; Coelho, P. S.; Arnold, F. H. Angew. Chem., Int. Ed. 2014, 53, 6810-6813.

(49) Gober, J. G.; Rydeen, A. E.; Gibson-O’Grady, E. J.; Leuthaeuser, J. B.; Fetrow, J. S.; Brustad, E. M. ChemBioChem 2016, 17, 394-397.

(50) Bordeaux, M.; Tyagi, V.; Fasan, R. Angew. Chem., Int. Ed. 2015, 54, 1744-1748.
(51) Bajaj, P.; Sreenilayam, G.; Tyagi, V.; Fasan, R. Angew. Chem., Int. Ed. 2016, 55, 16110-16114.

(52) Tinoco, A.; Steck, V.; Tyagi, V.; Fasan, R. J. Am. Chem. Soc. 2017, 139, 5293-5296.

(53) Sreenilayam, G.; Fasan, R. Chem. Commun. 2015, 51, 15321534.

(54) Tyagi, V.; Bonn, R. B.; Fasan, R. Chem. Sci. 2015, 6, 2488-2494.

(55) Kan, S. B. J.; Lewis, R. D.; Chen, K.; Arnold, F. H. Science 2016, $354,1048-1051$.

(56) Key, H. M.; Dydio, P.; Clark, D. S.; Hartwig, J. F. Nature 2016, 534, 534-537.

(57) Dydio, P.; Key, H. M.; Nazarenko, A.; Rha, J. Y.-E.; Seyedkazemi, V.; Clark, D. S.; Hartwig, J. F. Science 2016, 354, $102-106$

(58) Tyagi, V.; Fasan, R. Angew. Chem., Int. Ed. 2016, 55, 2512-2516.

(59) Tyagi, V.; Sreenilayam, G.; Bajaj, P.; Tinoco, A.; Fasan, R. Angew. Chem., Int. Ed. 2016, 55, 13562-13566.

(60) Mauksch, M.; Tsogoeva, S. B. Chem. - Eur. J. 2017, 23, 1026410269.

(61) Geng, Z.; Yan, P.; Wang, Y.; Yao, X.; Han, Y.; Liang, J. J. Phys. Chem. A 2007, 111, 9961-9968.

(62) Straub, B. F. J. Am. Chem. Soc. 2002, 124, 14195-14201.

(63) Xue, Y.-S.; Cai, Y.-P.; Chen, Z.-X. RSC Adv. 2015, 5, 5778157791.

(64) Shi, T.; Luo, Y.; Wang, X.-L.; Lu, X.; Zhao, Y.-L.; Zhang, J. Organometallics 2014, 33, 3673-3682.

(65) Fraile, J. M.; Garcia, J. I.; Martinez-Merino, V.; Mayoral, J. A.; Salvatella, L. J. Am. Chem. Soc. 2001, 123, 7616-7625.

(66) Dzik, W. I.; Xu, X.; Zhang, X. P.; Reek, J. N. H.; de Bruin, B. J. Am. Chem. Soc. 2010, 132, 10891-10902.

(67) Liu, J.; Hu, L.; Wang, L.; Chen, H.; Deng, L. J. Am. Chem. Soc. 2017, 139, 3876-3888.

(68) Khade, R. L.; Fan, W.; Ling, Y.; Yang, L.; Oldfield, E.; Zhang, Y. Angew. Chem., Int. Ed. 2014, 53, 7574-7578.

(69) Khade, R. L.; Zhang, Y. J. Am. Chem. Soc. 2015, 137, 75607563.

(70) Khade, R. L.; Zhang, Y. Chem. - Eur. J. 2017, 23, 17654-17658.

(71) Mansuy, D.; Lange, M.; Chottard, J. C.; Bartoli, J. F.; Chevrier, B.; Weiss, R. Angew. Chem., Int. Ed. Engl. 1978, 17, 781-782.

(72) Mansuy, D.; Battioni, J. P.; Lavallee, D. K.; Fischer, J.; Weiss, R. Inorg. Chem. 1988, 27, 1052-1056.

(73) Guerin, P.; Battioni, J. P.; Chottard, J. C.; Mansuy, D. J. Organomet. Chem. 1981, 218, 201-209.

(74) English, D. R.; Hendrickson, D. N.; Suslick, K. S. Inorg. Chem. 1983, 22, 367-368.

(75) Mbuvi, H. A.; Woo, L. K. Organometallics 2008, 27, 637-645.

(76) Sharon, D. A.; Mallick, D.; Wang, B.; Shaik, S. J. Am. Chem. Soc. 2016, 138, 9597-9610.

(77) Lu, H.; Dzik, W. I.; Xu, X.; Wojtas, L.; de Bruin, B.; Zhang, X. P. J. Am. Chem. Soc. 2011, 133, 8518-8521.

(78) Dzik, W. I.; Zhang, X. P.; de Bruin, B. Inorg. Chem. 2011, 50, 9896-9903.

(79) Comanescu, C. C.; Vyushkova, M.; Iluc, V. M. Chem. Sci. 2015, 6, 4570-4579.

(80) Li, F.; Xiao, L.; Li, Y.; Chen, C.; Liu, L. Chem. Commun. 2015, 51, 11964-11967.

(81) Meunier, B.; de Visser, S. P.; Shaik, S. Chem. Rev. 2004, 104, $3947-3980$.

(82) Zhang, Y.; Oldfield, E. J. Am. Chem. Soc. 2004, 126, 4470-4471.

(83) Ling, Y.; Davidson, V. L.; Zhang, Y. J. Phys. Chem. Lett. 2010, 1, 2936-2939.

(84) Liu, Y.; Xu, W.; Zhang, J.; Fuller, W.; Schulz, C. E.; Li, J. J. Am. Chem. Soc. 2017, 139, 5023-5026.

(85) Debrunner, P. G. In Iron Porphyrins; Lever, A. B. P., Gray, H. B., Eds.; VCH Publishers: New York, 1989; Vol. 3, pp 139-234.

(86) Khade, R. L.; Yang, Y.-W.; Shi, Y.-L.; Zhang, Y. Angew. Chem., Int. Ed. 2016, 55, 15058-15061.

(87) Sreenilayam, G.; Moore, E. J.; Steck, V.; Fasan, R. ACS Catal. 2017, 7, 7629-7633. 
(88) Bhagi-Damodaran, A.; Petrik, I. D.; Marshall, N. M.; Robinson, H.; Lu, Y. J. Am. Chem. Soc. 2014, 136, 11882-11885.

(89) Bhagi-Damodaran, A.; Kahle, M.; Shi, Y.; Zhang, Y.; Adelroth, P.; Lu, Y. Angew. Chem., Int. Ed. 2017, 56, 6622-6626.

(90) Ovalles, S. R.; Hansen, J. H.; Davies, H. M. L. Org. Lett. 2011, 13, 4284-4287.

(91) Tortoreto, C.; Rackl, D.; Davies, H. M. L. Org. Lett. 2017, 19, $770-773$.

(92) Hansen, S. R.; Spangler, J. E.; Hansen, J. H.; Davies, H. M. L. Org. Lett. 2012, 14, 4626-4629.

(93) Frisch, M. J.; Trucks, G. W.; Schlegel, H. B.; Scuseria, G. E.; Robb, M. A.; Cheeseman, J. R.; Scalmani, G.; Barone, V.; Mennucci, B.; Petersson, G. A.; Nakatsuji, H.; Caricato, M.; Li, X.; Hratchian, H. P.; Izmaylov, A. F.; Bloino, J.; Zheng, G.; Sonnenberg, J. L.; Hada, M.; Ehara, M.; Toyota, K.; Fukuda, R.; Hasegawa, J.; Ishida, M.; Nakajima, T.; Honda, Y.; Kitao, O.; Nakai, H.; Vreven, T.; Montgomery, Jr., J. A.; J. Peralta, E.; Ogliaro, F.; Bearpark, M.; Heyd, J. J.; Brothers, E.; Kudin, K. N.; Staroverov, V. N.; Keith, T.; Kobayashi, R.; Normand, J.; Raghavachari, K.; Rendell, A.; Burant, J. C.; Iyengar, S. S.; Tomasi, J.; Cossi, M.; Rega, N.; Millam, J. M.; Klene, M.; Knox, J. E.; Cross, J. B.; Bakken, V.; Adamo, C.; Jaramillo, J.; Gomperts, R.; Stratmann, R. E.; Yazyev, O.; Austin, A. J.; Cammi, R.; Pomelli, C.; Ochterski, J. W.; Martin, R. L.; Morokuma, K.; Zakrzewski, V. G.; Voth, G. A.; Salvador, P.; Dannenberg, J. J.; Dapprich, S.; Daniels, A. D.; Farkas, O.; Foresman, J. B.; Ortiz, J. V.; Cioslowski, J.; Fox, D. J. Gaussian 09, Revision B.01; Gaussian, Inc.: Wallingford, CT, 2010.

(94) Mennucci, B.; Tomasi, J. J. Chem. Phys. 1997, 106, 5151-5158.

(95) Torres, R. A.; Lovell, T.; Noodleman, L.; Case, D. A. J. Am. Chem. Soc. 2003, 125, 1923-1936.

(96) Chai, J.-D.; Head-Gordon, M. Phys. Chem. Chem. Phys. 2008, 10, 6615-6620.

(97) Yang, K.; Zheng, J.; Zhao, Y.; Truhlar, D. G. J. Chem. Phys. 2010, 132, 164117.

(98) Hay, P. J.; Wadt, W. R. J. Chem. Phys. 1985, 82, 270-283.

(99) Schroder, D.; Shaik, S.; Schwarz, H. Acc. Chem. Res. 2000, 33, 139-145.

(100) Poli, R.; Harvey, J. N. Chem. Soc. Rev. 2003, 32, 1-8.

(101) Ling, L.; Liu, K.; Li, X.; Li, Y. ACS Catal. 2015, 5, 2458-2468.

(102) Hu, L.; Chen, H. J. Am. Chem. Soc. 2017, 139, 15564-15567.

(103) Tahsini, L.; Bagherzadeh, M.; Nam, W.; de Visser, S. P. Inorg. Chem. 2009, 48, 6661-6669.

(104) Davies, H. M. L.; Grazini, M. V. A.; Aouad, E. Org. Lett. 2001, 3, 1475-1477.

(105) Berry, E. A.; Trumpower, B. L. Anal. Biochem. 1987, 161, 115 . 